\title{
Absence of Saharan dust influence on the strontium isotope ratios on modern trees from the Bahamas and Turks and Caicos Islands
}

Rick Schulting1, School of Archaeology, University of Oxford, UK

Mike Richards, Department of Archaeology, Simon Fraser University, BC, Canada John Pouncett, School of Archaeology, University of Oxford, UK

Bryan Naqqi Manco, Caicos Pine Recovery Project Manager, Department of Environment and Coastal Resources, Turks and Caicos Islands

Ethan Freid, Bahamas National Trust/Leon Levy Native Plant Reserve, Bahamas Joanna Ostapkowicz, School of Archaeology, University of Oxford, UK

\footnotetext{
${ }^{1}$ Corresponding author: rick.schulting@arch.ox.ac.uk
}

Telephone: +44 (0)1865 278309 
3 We report on strontium $\left({ }^{87} \mathrm{Sr} /{ }^{86} \mathrm{Sr}\right)$ isotope results from 91 modern trees growing on the

4 Bahamas and Turks and Caicos Islands. The average ${ }^{87} \mathrm{Sr} /{ }^{86} \mathrm{Sr}$ ratio of $0.709169 \pm 0.000010$

5 is consistent with the late Quaternary limestone of the islands and with the modern ocean

6 value. The absence of any detectable influence of ${ }^{87} \mathrm{Sr}$-enriched Saharan dust is notable,

7 given the known contribution of this material to both past and recent soils of the

8 Caribbean. Our results indicate that the impact of Saharan dust to the modern biosphere of

9 the Bahamian archipelago is at least an order of magnitude less than modeled in currently

10 available strontium isoscapes for the circum-Caribbean. We suggest that the bioavailability

11 of Sr in Saharan dust may be considerably less than previously thought. Nevertheless,

12 further work could usefully be carried out in the Bahamian archipelago on plants with

13 different rooting depths, growing on different soil types and on limestone of different ages.

14 Our results have particular relevance for the refinement of existing strontium isoscapes

15 and the archaeological provenience of artifacts, animals and people in the circum-

16 Caribbean.

Keywords: Caribbean; Bahamian archipelago; strontium isoscape; carbonate; Saharan dust 
Atmospheric dust inputs are known to be an important factor affecting strontium isotope $\left.{ }^{87} \mathrm{Sr} /{ }^{86} \mathrm{Sr}\right)$ ratios in the biosphere. This makes the use of bedrock or surficial geological maps to predict ${ }^{87} \mathrm{Sr} /{ }^{86} \mathrm{Sr}$ in living organisms potentially unreliable for provenience studies in both ecology and archaeology. In the circum-Caribbean, Saharan dust in particular is understood to have had a significant impact on development of paleosols on the Pleistocene terraces of carbonate islands exposed during periods of lowered sea levels (Muhs et al., 1990; Foos, 1991; Foos and Bain, 1995; Boardman et al., 1995; Borg and Banner, 1996; Herwitz et al., 1996). This dustfall continues into the present, and is an important source of mineral nutrients for the Caribbean basin's biosphere (Delaney et al., 1967; Prospero and Carlson, 1972; Prospero and Nees, 1986; Goudie and Middleton, 2001; Formenti et al., 2011; Prospero and Mayol-Bracero, 2013). Its contribution is of particular relevance to the mineral-impoverished, high-purity carbonate islands of the Bahamian archipelago. Because of its relatively high ${ }^{87} \mathrm{Sr} /{ }^{86} \mathrm{Sr}$ ratio, Saharan dust would be expected to have an influence on the isotopic composition of vegetation, as has been recently modeled in a strontium isoscape for the Caribbean (Bataille et al., 2012; Laffoon et al., 2012). In this paper, we present the results of a program of ${ }^{87} \mathrm{Sr} /{ }^{86} \mathrm{Sr}$ measurements on modern trees (primarily Swietania sp. and Guaiacum sp.) from the Bahamas ( $\mathrm{n}=37)$ and the Turks and Caicos Islands (TCI) $(n=54)$ (Figure 1). To our knowledge these are the first such data to be reported from the terrestrial biosphere of these islands. The aim is to determine the extent to which modern ${ }^{87} \mathrm{Sr} /{ }^{86} \mathrm{Sr}$ measurements are influenced by legacy and ongoing allochthonous inputs, the most important of which is expected to be Saharan dust (others 
include sea-spray, volcanic ashfall, and dust from the Mississippian loess belt). Our study builds on previous work in the region, and serves in part as a test of the predictions made by Bataille et al.'s (2012) strontium isoscape. Ultimately, the intention is to use these data in conjunction with other isotopic datasets being produced in the circum-Caribbean, to facilitate studies of the origins and mobility of pre-Columbian humans, animals and artifacts (Laffoon et al., 2012; 2014; 2016; 2017; Ostapkowicz et al., 2017). The results may also be of interest to those creating isoscapes in other parts of the world (Evans et al., 2010; Snoeck et al., 2016) and to those studying pedogenesis and soil processes using Sr as a tracer for calcium cycling (e.g., Åberg et al., 1990; Reynolds et al., 2012).

\section{Strontium isotope studies in the circum-Caribbean} (1)

Strontium (Sr) is an alkaline earth metal with four naturally occurring isotopes, ${ }^{84} \mathrm{Sr}$ (0.56\%), ${ }^{86} \mathrm{Sr}(9.86 \%),{ }^{87} \mathrm{Sr}(7.00 \%)$, and ${ }^{88} \mathrm{Sr}(82.58 \%)$ (Faure, 1986). The most important of these for provenience studies is ${ }^{87} \mathrm{Sr}$, deriving from the $\beta$ decay of rubidium $\left({ }^{87} \mathrm{Rb}\right)$. Thus, the ratio of ${ }^{87} \mathrm{Sr} /{ }^{86} \mathrm{Sr}$ will depend on the amount of rubidium originally found in the rock, and the passage of deep time (Faure, 1986). In a Caribbean context, young geological formations such as those of the volcanic arc of the Lesser Antilles can have ${ }^{87} \mathrm{Sr} /{ }^{86} \mathrm{Sr}$ ratios as low as 0.704 , while those of older sedimentary and metamorphic formations will have higher ratios of up to 0.715 (e.g., Pushkar et al., 1973; Borg and Banner, 1996; Laffoon et al., 2012; Ostapkowicz et al., 2017). Most ratios, including those of marine carbonates, fall between these extremes. Strontium becomes incidentally incorporated in lieu of calcium into the tissues of a tree (or other plant) when taken up in solution during the course of the tree's life (Faure, 1986; Capo et al., 1998). It will therefore reflect the bioavailable ${ }^{87} \mathrm{Sr} /{ }^{86} \mathrm{Sr}$ 
ratio of that location, which in turn will be comprised of a combination of Sr from a number of sources, the most important of which will usually be bedrock weathering.

The surface exposures of the Bahamian archipelago (comprising the Bahamas and TCI) are composed entirely of Quaternary limestone, with the most widespread deposits being those of the late Pleistocene Grotto Beach Formation (Marine Isotope Stage 5e) (Carew and Mylroie, 1985; 1995; Mylroie and Carew, 1995; Carew and Mylroie, 1997; Mylroie et al., 2012; see also Wanless et al., 1989 for TCI), dating to 132-119 ka (Chen et al., 1991). This in turn is often overlain by lithified intertidal and aeolian-derived deposits of the Holocene Rice Bay Formation (Mylroie and Carew, 1995; Carew and Mylroie, 1997). While ${ }^{87} \mathrm{Sr} /{ }^{86} \mathrm{Sr}$ ratios exhibit a more or less linear increase over the course of the Pleistocene, no trend is readily apparent for the last $130 \mathrm{ka}$, during which time ratios do not depart significantly from the contemporary ocean value of ca. 0.70917 (Capo and DePaolo, 1990; Hodell et al., 1990; Dia et al., 1992; Henderson et al., 1994; McArthur, 1994), although slightly higher values of ca. 0.70920 have also been reported (Kuznetsov et al., 2012). While middle Pleistocene deposits have long been recognized in the Bahamas (Owl's Hole Formation), they are almost always overlain by late Pleistocene deposits, and are usually exposed only on sea cliffs or in modern road cuts and quarries (Carew and Mylroie, 1985; 1995; Hearty and Kindler, 1993; 1997; Hearty, 1998). The Miocene and early Pleistocene deposits recently identified along the north coast of the island of Mayaguana have not yet been recognized elsewhere in the archipelago (Kindler et al., 2011). Strontium isotope ratios on middle Pleistocene (0.34-0.88 Ma) carbonate samples from the island average $0.709155 \pm$ $0.000009(n=4)$, significantly lower than the abovementioned late Pleistocene value of ca. 0.70917 . 
The ${ }^{87} \mathrm{Sr} /{ }^{86} \mathrm{Sr}$ ratio of ca. 0.70917 for modern seawater is closely comparable to that observed in a range of marine taxa (gastropods, bivalves, foraminifera, echinoderms, algae and coral) on Lee Stocking Island, Bahamas, spanning habitats from the coral reefs to mangrove swamps, averaging $0.709179 \pm 0.000012(n=40)$ and confirming the absence of vital effects, i.e., fractionation (Reinhardt et al., 1999). However, the relationship of bioavailable $\mathrm{Sr}$ to the local geology is not always straightforward, especially in terrestrial systems (Sillen et al., 1998, Evans et al., 2010; Hartman and Richards, 2014; Snoeck et al., 2016), being affected by a combination of weathered Sr from the underlying bedrock (Bain and Bacon, 1994), Sr deposited in rainfall and sea-spray (Vitousek et al., 1999; Whipkey et al., 2000; Montgomery et al., 2003; Hodell et al., 2004; Evans et al., 2010), as well as Sr in wind-borne dust and soil particles (Prospero et al., 1981; Reynolds et al., 2012). The potential impact of Saharan dust on the Bahamian archipelago's biosphere is clear from its ${ }^{87} \mathrm{Sr} /{ }^{86} \mathrm{Sr}$ ratio of ca. 0.716-0.718 (Grousset and Biscaye, 1989; 2005; Grousset et al., 1992;

Rognon et al., 1996), which is considerably higher than that of ca. 0.7092 for late Quaternary limestone. The extent of its impact will depend on the relative amounts of $\mathrm{Sr}$ found in these two sources and on their bioavailability.

Saharan dust has been identified as an important contributor to both past and present soils from the Lesser Antilles to Florida, with its strongest expression in the so-called 'red soils' that formed during Pleistocene stadials (Delaney et al., 1967; Syers et al., 1969; Prospero and Nees, 1986; Prospero et al., 1987; Muhs et al., 1987; 1990; Borg and Banner, 1996; Prospero, 1999; Kamenov et al., 2009). Prospero and Mayol-Bracero (2013) refer to the Caribbean basin as a major "receptor" site for Saharan dust, which accounts for over half of modern global dust emissions. It has been estimated that some 30 to 50 million tonnes of Saharan dust falls on the Caribbean annually (Prospero and Carlson, 1972; Colcaro et al., 
123

124

125

126

127

128

129

130

131

132

133

134

135

136

137

138

139

140

141

142

143

144

145

146

2003; Kaufman et al., 2005; see also Prospero et al. 1987). On the basis of a detailed geochemical study of paleosols from Barbados, the Bahamas, and the Florida Keys, Muhs et al. (1990:171; see also Muhs et al., 2007) state that "Saharan dust has been the major parent material for soils on Quaternary limestones of Caribbean and western Atlantic islands in the last 900,000 yr". Moreover, it is now widely accepted that it is difficult to develop soils on young limestone islands from bedrock dissolution alone, again emphasizing the importance of atmospheric dust sources, including Mississippi River Valley loess, volcanic ash and Saharan dust (Syers et al., 1969; Bricker and Mackenzie, 1970; Muhs et al., 1987; 1990; Boardman et al., 1995; Prognon et al., 2011). For the western Caribbean specifically, the contribution of volcanic dust has been shown to be negligible, and, while Mississippian loess may be a minor contributor in the more northern islands, the dominant source is clearly North African dust (Muhs et al., 2007).

There have been a number of studies from a range of disciplines employing Sr isotopes in the circum-Caribbean region. Recently, there has been considerable interest from the archaeological community in the use of strontium and other isotopes to trace the provenience of artifacts, animals and people (Laffoon and Hoogland, 2012; Laffoon et al., 2012; 2014; 2016; 2017; Ostapkowicz et al., 2012; 2013; 2017; Pestle et al., 2013). Bataille et al. (2012) have developed a sophisticated Sr isoscape taking into account the contributions of island bedrock geology, differential weathering of rock types, rainfall and atmospheric dust deposition. However, the availability of biologically available baseline data to validate their model is still spatially patchy. In particular, the model includes no data relating to the terrestrial environment of the Bahamas/TCI. 
Here, we present strontium isotope data on 91 modern trees from seven islands spanning some $600 \mathrm{~km}$ of the Bahamian archipelago, to assess whether any isotopically distinct allochthonous inputs can be detected. Previous studies have suggested that highly weatherable carbonate bedrock will dominate over the contribution of ${ }^{87} \mathrm{Sr}$-enriched

151 Saharan dust, though not override it entirely (Bataille et al., 2012:13, Fig. 5; see also Bern et al., 2005). Thus, the extent of the latter's potential impact is unclear. While carbonate bedrock will undergo high rates of weathering, in the absence of a developed soil containing clay minerals, this material will not be retained. Balancing this, Saharan dust is an annual input. Furthermore, vegetation itself acts as a dust trap, with subsequent throughfall supplying further aeolian sediments to the soil (Graustein and Armstrong, 1983; Lovett and Lindberg, 1984; Gosz and Moore, 1989; Åberg et al., 1990; Reynolds et al., 2012).

By the time it reaches the Caribbean, deposition of Saharan dust is mainly through wet 161 removal processes, with dust particles acting as cloud condensation nuclei (Nowottnich et al., 2011). This is particularly relevant to our study in that the Bahamas not only receive substantially higher annual precipitation than TCI (800-1100 mm/yr vs. 400-800 mm/yr),

164 but rainfall is concentrated in the summer months in the former, versus the winter months 165 in the latter (Sears and Sullivan 1978; Whitaker and Smart, 1997) (Figure 2). Because 166 Saharan dust transport to the Caribbean occurs primarily in the summer months (Prospero 167 et al., 1981; Prospero, 1999; Goudie and Middleton, 2001; Colcaro et al., 2003; Prospero 168 and Lamb, 2003; Prospero et al., 2014), we might expect the Bahamas to receive higher 169 inputs of Saharan dust than TCI. Counteracting this, and responsible for the opposite trend 170 modeled by Bataille et al. (2012: Fig. 5) is the reduced bedrock weathering resulting from 171 lower average rainfall in the southern archipelago (including TCI), but, as acknowledged by 
the authors, this does not take into account the potential impact of the strong seasonal bias resulting from the combination of summer precipitation and the presence of Saharan dust. There is a clear precipitation gradient even within the Bahamas that is partly captured by our dataset, with Long Island to the south receiving approximately half the rainfall of Cat Island and Eleuthera to the north. This effect increases in the northern Bahamian islands, culminating in Andros, where summer rainfall is twice as high as on Eleuthera.

Unfortunately our study does not include samples from the northern islands. Though the atmospheric dust sources differ from those being considered here, it is worth noting that Gosz and Moore (1989) demonstrated a marked seasonal shift in ${ }^{87} \mathrm{Sr} /{ }^{86} \mathrm{Sr}$ ratios in precipitation in the mountains of New Mexico. This effect has yet to be demonstrated empirically for our study region, but underlies one of our research questions.

We test the following hypotheses:

1) Saharan dust will have a small but detectable effect on trees growing on the Bahamian archipelago, raising ${ }^{87} \mathrm{Sr} /{ }^{86} \mathrm{Sr}$ ratios above those of the late Quaternary deposits, as modeled by Bataille et al. (2012: Fig. 5B).

2) The impact of Saharan dust may exhibit an increasing southeast to northwest gradient, paralleling the summer precipitation gradient, when atmospheric dust of North African origin is also at its peak (thus, we are testing the reverse of the pattern expected from Bataille et al.'s model in this respect, for reasons discussed above).

3) The impact of Saharan dust may be greater in smaller trees with shallower rooting systems, whereas larger trees with deeper rooting systems will be dominated by bedrock ${ }^{87} \mathrm{Sr} /{ }^{86} \mathrm{Sr}$ ratios (Reynolds et al., 2012; Hartman and Richards, 2014; though see Poszwa et al. (2002) who found that deep roots contributed little or no Sr to trees in a tropical 
rainforest, but that instead there is a focus on the uppermost soils where fine rootlets concentrate to take advantage of nutrients from leaf litter).

4) The impact of Saharan dust may differ according to topography and/or elevation, with

199 less accumulation on ridges as opposed to planes and other low-lying areas and swales

200 ('channels') having greater potential for the accumulation of dust over recent time as well

201 as tending to be foci for lateritic 'red soil' paleosols (Little et al., 1977: 54; Wanless et al., 202 1989: 53).

203 5) The impact of Saharan dust will be marginally higher in 'inland' areas, here defined as 204 lying more than $1 \mathrm{~km}$ from the coast, since these are more protected from coastal erosion 205 and so may have greater soil depth.

206 6) The impact of Saharan dust will be greater in trees growing on clay-rich loams,

207 particularly the 'red soils' derived from Saharan dust, than those growing on coral sands.

208

209 Note that (5) and (6) are not independent, since the coral sands are primarily coastal 210 though on occasion they do extend 'inland' by more than $1 \mathrm{~km}$. While the effects in all cases 211 are expected to be small because of the predominant contribution of carbonate bedrock-

212 derived $\mathrm{Sr}$, our relatively large sample size together with the isotopic homogeneity of the 213 islands' late Quaternary bedrock deposits should enable us to detect even slight shifts 214 towards higher ${ }^{87} \mathrm{Sr} /{ }^{86} \mathrm{Sr}$ ratios, should they exist. Thus, the Bahamian archipelago is well 215 suited for testing the potentially subtle effects of Saharan dust on ${ }^{87} \mathrm{Sr} /{ }^{86} \mathrm{Sr}$ ratios in living 216 vegetation growing over carbonate bedrock in the western Caribbean. 
Ninety-one samples from living trees were collected in 2009 from Eleuthera $(n=2)$, Cat

221 Island $(n=15)$ and Long Island $(n=20)$ in the Bahamas, and from Providenciales $(n=12)$

222 and North $(n=21)$ Middle $(n=14)$ and East Caicos $(n=7)$ in TCI (Figures $1,3-4)$. The

223 majority of the samples collected were of Guaiacum sanctum $(\mathrm{n}=44)$ and Swietenia

224 mahagoni $(\mathrm{n}=36)$, since these taxa have been identified as among the most commonly

225 used for pre-Columbian woodcarvings in the Bahamas and TCI (Ostapkowicz et al., 2012;

226 Ostapkowicz, 2015). Smaller numbers of samples of G. officinale $(\mathrm{n}=4)$, Zanthoxylum

227 flavum $(\mathrm{n}=4)$, Cordia sebestina $(\mathrm{n}=2)$ and Lysiloma latisiliquum $(\mathrm{n}=1)$ were also

228 collected; these species too are known to have been used in pre-Columbian woodcarving.

229 One of the original aims of this project was to develop baseline data for the interpretation

230 of ${ }^{87} \mathrm{Sr} /{ }^{86} \mathrm{Sr}$ ratios obtained on these artifacts (Ostapkowicz et al., 2012), and using the

231 same taxa for the modern study removed a potentially confounding variable. Guaiacum and

232 Swietenia are CITES-listed (Convention on International Trade in Endangered Species), and

233 the project fully complied with all regulations pertaining to the documentation and

234 export/import of specimens [CITES permit nos. 2009/356 [Bahamas] and PLS-W-2009-39,

$235417091 / 01$ [Turks and Caicos]). As part of the agreement with the national agencies,

236 botanical specimens were collected from the same trees, and were dried and prepared for

237 herbarium collections in national institutions in the Bahamas and TCI, with another archive

238 held in the World Museum Liverpool. Field sampling was undertaken with botanists from

239 the National Trusts of the Bahamas (EF) and Turks and Caicos Islands (BNM), who

240 provided in-field species identifications.

242 Potentially relevant is the rooting depth of these genera-among the largest indigenous

243 trees on the islands-which could tap into the rare deeper soils that include aeolian inputs

244 accumulated over decades or more, or, alternatively, beneath the shallow soil horizon 
entirely into carbonate bedrock, whereas shallow-rooting plants might predominantly reflect leaf litter and more recent inputs over the last few years. However, over-harvesting of Guaiacum and Swietenia in the 17-19th centuries has left few surviving groves in the Bahamas and TCI (Correll and Correll, 1982:26). Most are found in what is known locally as

249 'coppice' wood, and many take the form of bushes rather than full size trees. In any case, a 250 study by Pozwa et al. (2002) suggests that in nutrient-poor soils-which certainly describe

251 the Bahamian archipelago-Sr uptake will focus on the near-surface layer. Moreover, soils 252 across the study region are generally thin, often only a few centimeters over bedrock, 253 though some solution holes ('banana holes') have become infilled to depths of a few meters 254 (Mooney, 1905; Little et al., 1977).

Once a grove or individual tree was identified, GPS coordinates and detailed information on tree size and environment were documented, and each sampled tree was photographed.

Twigs of ca. $1 \mathrm{~cm}$ in diameter were taken from trees ranging in height from ca. 1 to $12 \mathrm{~m}$

259 (averaging ca. $4.1 \pm 2.0 \mathrm{~m}$ ), and from ca. 0.05 to $0.5 \mathrm{~m}$ in diameter at chest height (averaging ca. $0.25 \pm 0.10 \mathrm{~m}$ ). Only the branchwood was used for Sr isotope analysis, and so reflects

261 growth over a period of 2-4 years. For the purposes of analysis, trees were divided into 262 three size classes: small (0.05-0.20m diam at chest height, 1.0-3.0m height), medium $263(0.20-0.40 \mathrm{~m}$ diam, 3.0-5.0m height) and large $(>0.40 \mathrm{~m}$ diam, $>5.0 \mathrm{~m}$ height $)$. Appropriate 264 size information was recorded for 86 trees (measurements for five trees were not 265 recorded).

267 Collection sites were chosen to provide wide coverage of the selected islands (which were 268 themselves chosen based on the known presence of the target tree species) to investigate 269 possible subtle differences in Sr isotope ratios, e.g., between coast and interior, defined as 
$<>1 \mathrm{~km}$ from the coast, respectively, and between landforms. This coast-inland division was chosen primarily because transects on both the west and east coasts of Ireland suggest that the effects of sea-spray on ${ }^{87} \mathrm{Sr} /{ }^{86} \mathrm{Sr}$ ratios in the biosphere do not extend past $1 \mathrm{~km}$ on carbonate bedrock (Snoeck, 2014). This is in contrast to other studies reporting stronger and more widespread impacts of sea-spray and/or rainfall (Vitousek et al., 1999; Whipkey et al., 2000; Montgomery et al., 2003; Hodell et al., 2004), but these studies refer to regions dominated by basaltic or granitic bedrocks that are far more resistant to weathering than limestone, and so are more readily affected by allochthonous inputs (cf. Bataille et al., 2012).

Morphometric characterization of landform at the sample locations was carried out using 1 arc second (ca. 30m at the equator) Shuttle Radar Topography Mission (SRTM) void-filled digital elevation model ${ }^{1}$ in Landserf 2.3.1 (Wood, 2009). Cells in a digital elevation model can be classified as pits, channels, passes, ridges, peaks or planes using unique criteria based on four surface parameters: slope, cross-sectional curvature, maximum curvature and minimum curvature (Wood, 1996). Surface parameters are calculated using quadratic approximation, fitting a quadratic trend surface through all of the data points corresponding to the cells in an $\mathrm{n} \times \mathrm{n}$ window and calculating the values of the parameters for the cell at its centre. The values of the surface parameters and the subsequent characterization of the morphometric feature types are scale dependent, i.e. dependent on the size of the $\mathrm{n} x \mathrm{n}$ window. Multiscalar characterization can be performed by calculating fuzzy feature classes, with values for each morphometric feature type ranging between 0 (not classified as that feature type at any scale of analysis) and 1 (classified as that feature type at all scales of analysis). Fuzzy feature classes were calculated for the Bahamas and

\footnotetext{
${ }^{1}$ https://lta.cr.usgs.gov/SRTMVF
} 
294 Turks and Caicos Islands for window sizes between 3 and 31, equivalent to planimetric 295 distances of between c.100m and c.1km. Dominant feature types for the sample locations 296 were determined on the basis of the fuzzy feature class with the highest value (ridges, $\mathrm{n}=$ 297 11; planes, $n=74$, and; channels, $n=3$ ). The fuzzy feature classes for the sample locations 298 were also reclassified as negative features (pits $>0$ or channels $>0$ or passes $>0$ ) or 299 positive features (ridges $>0$ or peaks $>0$ ) in order to determine locations where sediments 300 were likely to accumulate and locations where erosion was likely to have occurred 301 (negative, $\mathrm{n}=21$, and; positive, $\mathrm{n}=35^{1}$ ).

303 We have soil maps only for Long and Cat Islands (we have been unable to source any from 304 TCI), and have plotted sampling locations against areas identified as Bahama Black Loam (n $305=18)$, Bahama Red Loam $(n=5)$, Coral Sands $(n=10)$ and Brackish Swamp $(n=2)$

306 (Mooney 1905) (Figure 5). Field observations suggest that the two locations on what were 307 identified as 'Brackish Swamp' in the early $20^{\text {th }}$ century may have since been drained as 308 part of now largely abandoned attempts to improve soil fertility for agriculture (Little et al., 309 1997). The designation is retained here, since there may be a legacy effect on these soils.

310 The lateritic clay-rich 'Red Loam' represents exposed Pleistocene paleosols with high 311 concentrations of Saharan dust. They can range in color from deep red (Munsell 10Y 2/2) 312 to light yellow-brown (10YR 7/6), mainly reflecting diagenetic processes (Foos and Bain, 313 1995). Unfortunately these are the least well represented in our study, since testing soil 314 differences was not an original aim of the project. Nevertheless, because Saharan dustfall is 315 an annual input, its contribution might be reasonably expected to feature in all soils to 316 some extent (Prospero and Carlson, 1972; Colcaro et al., 2003; Kaufman et al., 2005;

\footnotetext{
${ }^{1}$ Locations that were classified as positive features at one or more scales of analysis and negative features at one or more scales of analysis were excluded from these counts.
} 
317 Prospero and Mayol-Bracero, 2013). The contribution of Saharan dust to other soils in the

318 Bahamas is confirmed by its presence in trace amounts even in coral sands (Foos and Bain,

319 1995). Furthermore, the relatively organic-rich 'black soils' that dominate our sampling

320 locations - in addition to containing the Sr taken up by decomposing plants during life-

321 should also trap and hold the Saharan dust that continues to fall each summer. This is

322 because strontium cations $\left(\mathrm{Sr}^{2+}\right)$ will be relatively strongly adsorbed onto negatively

323 charged clay minerals and organic matter (Capo et al., 1998:201, 208). Indeed, pre-

324 Holocene peat samples from San Salvador and Andros were found to contain significant

325 amounts of boehmite, a marker for Saharan dust (Boardman et al., 1995:44), clearly

326 demonstrating that the latter's impact is not restricted to the 'red soils'.

328 A caveat in terms of the application of our findings to the pre-Columbian period is that the 329 soils of the Bahamian archipelago have been heavily eroded following deforestation in the 330 early colonial period and so may not fully reflect the earlier situation. The transport of 331 Saharan dust over the Caribbean has also varied over time, particularly as a result of 332 precipitation over the Sahel and of the strength of winds over the dust source regions 333 (Prospero and Lamb, 2003; Ridley et al., 2014). Nevertheless, data from 2002-2011, 334 encompassing sample collection in July 2009, shows that these years all recorded 335 substantial summer Saharan dustfall in the Caribbean (Prospero et al., 2014: Fig. 7).

\section{Strontium isotope analysis}

339 Branchwood samples were prepared for Sr isotope analysis following methods outlined in 340 Reynolds et al. (2005). Samples ranging in size from 20 to $100 \mathrm{mg}$ were first cleaned in 341 ultrapure water and then ashed at $850^{\circ}$ before being prepared following standard $\mathrm{Sr}$ 
isotope preparation procedures and measurement using a ThermoFinnigan Neptune Inductively-Coupled Plasma Multi-Collectors Mass Spectrometer (MC-ICP-MS) at the

344 Department of Human Evolution, Max Planck Institute of Evolutionary Anthropology,

345 Leipzig, Germany (see details in Copeland et al., 2008). For quality assurance,

346 measurements runs included the international Standard Reference Material (SMR) 1486,

347 and samples were corrected using the SRM 987 strontium carbonate isotopic standard

348 (https://www.nist.gov/srm). Measurement errors are on the order of +/- 0.00003, based 349 on long-term repeat analyses of SRM 1486 at the Max Planck Institute.

351 Statistical tests were carried out in SPSS. Data were assessed for normality and parametric 352 or nonparametric tests were applied as appropriate (the latter were not required).

353 Heteroscedastic tests were applied in cases when variance was not homogeneous.

\section{RESULTS}

The ${ }^{87} \mathrm{Sr} /{ }^{86} \mathrm{Sr}$ isotope ratios obtained on 91 samples are extremely homogeneous, with a mean of $0.709169 \pm 0.000010$ and a coefficient of variation of only $0.001 \%$ (Tables 1 and 2 ;

Figure 6). The data are normally distributed (Shapiro-Wilk test, $W=0.983, p=0.295$ ), with

360 only four samples lying more than two standard deviations from the mean (see Z-scores in

361 Table 1); this is approximately what would be expected given the sample size. In terms of

362 the hypotheses set out in the paper:

363 1) There is no detectable ${ }^{87} \mathrm{Sr}$-enrichment as a result of Saharan dust, as the overall mean of $3640.709169 \pm 0.000010$ is indistinguishable to five decimals places from modern seawater 365 (Hodell et al., 1990; Dia et al., 1992; Henderson et al., 1994; McArthur, 1994). 
2) There is no difference between the means of the island groups, with the Bahamas averaging $0.709170 \pm 0.000007(n=37)$ and TCI averaging $0.709168 \pm 0.000012(n=54)$

368 (heteroscedastic Student's t-test, $t=0.96, p=0.34$ ). However, the TCI results are significantly more variable (F-test, $F=2.46, p=0.005$ ), including the four highest and seven lowest measurements in the dataset (Figure 6). There are no differences in the means of

371 the individual islands independent of island group (ANOVA, $F=0.31, p=0.93, \mathrm{df}=6,83$ ).

372 Together, these two tests also act as a proxy for assessing the postulated positive

373 relationship with summer precipitation, for which no evidence is seen. This also tests for 374 the east to west pattern of decreasing impact of Saharan dust modelled by Bataille et al. 375 (2012), and again no such trend can be observed.

3) There is no difference between the three tree size classes (ANOVA $F=0.18, p=0.84$, $\mathrm{df}=$ 3772 2, 83). No difference between tree species was anticipated, since samples from the two main species targeted each reflect the full range of tree size and so would be expected to

379 have similar rooting depth, nor do they have different habitat requirements, and indeed are 380 sometimes found growing near one another (e.g., Figure 3b, samples L16 and L17). The 381 lack of any effect in this regard was confirmed (ANOVA, $F=1.07, p=0.36, \mathrm{df}=3,84$ ). 382 4) There is no difference by topographical location (planes, ridges and channels: ANOVA, $F$ $383=0.34, p=0.71, \mathrm{df}=2,85$; negative and positive positions: Student's $t$-test, $t=1.17 ; p=$ $3840.25 ; \mathrm{df}=54$ ), or elevation (linear regression model, $r^{2}=0.00, p=0.52, \mathrm{n}=88$ ).

3855 ) There is no difference between coastal ( $n=49$, defined as within $1 \mathrm{~km}$ of the coast) and 386 'inland' locations ( $\mathrm{n}=39)$, as far as the latter can be said to exist on the small, low-lying 387 islands of the archipelago (Student's t-test, $t=1.14, p=0.26, \mathrm{df}=86$ ).

388 6) No differences are seen between the four recorded Bahamian soil types (Bahamas Black 389 Loam, Bahamas Red Loam, Coral Sand and Brackish Swamp), which are all identical to five 390 decimals with the overall average of 0.70917 (ANOVA, $F=0.42, p=0.74, \mathrm{df}=3,31$ ). Two 
samples from Middle Caicos (M7 and M12 in Table 1), noted in the field as growing on reddish/yellow-brown soils have ratios of 0.709169 and 0.709165 , respectively at and slightly below the average both for Middle Caicos, and for all islands combined.

\section{DISCUSSION}

The ${ }^{87} \mathrm{Sr} /{ }^{86} \mathrm{Sr}$ taken up by trees across the Bahamas and TCI is consistent with an entirely autochthonous origin. A caveat here is the expected contribution of Sr in sea-spray, which affects the ${ }^{87} \mathrm{Sr} /{ }^{86} \mathrm{Sr}$ ratios of both soils and plants along the coasts of many Caribbean islands (Bataille et al., 2012; Laffoon et al., 2012; Pestle et al., 2013). But this will not be

401

402

403

404 detectable in the Bahamian archipelago, since the value for sea-spray will be indistinguishable from that of the islands' late Quaternary limestone bedrock (cf. Borg and Banner 1996). Furthermore, in Sr-rich carbonate formations (ca. 610 ppm), seawater (7-8 ppm) is not expected to be a significant factor (Faure, 1986; Angino et al., 1996; Borg and Banner, 1996; see also Snoeck, 2014). Rainfall is more complicated, since in the summer months it will contain Saharan dust particles, and so have a combination of Sr from both seawater and dust sources, though the concentration of $\mathrm{Sr}$ in precipitation is orders of magnitude less than in seawater ( $<0.1$ ppm; Faure, 1986; Capo et al., 1998) apart from its dust nuclei (200-300 ppm; Grousset et al., 1992; Rognon et al., 1996; Grousset and Biscaye, 2005). Therefore, precipitation on its own will not be a significant contributor of Sr.

More noteworthy for the present discussion is the absence of evidence for any measureable input in the overall dataset from atmospheric dust sources with different ${ }^{87} \mathrm{Sr} /{ }^{86} \mathrm{Sr}$ ratios, whether lower ratios from volcanic ashfalls (ca. 0.707), or higher ratios from Saharan dust (ca. 0.716-0.718) (Grousset et al., 1992; Kroma et al., 1999; Grousset and Biscaye, 2005; 
416 Formenti et al., 2011; Aarons et al., 2013). Even if present in only small amounts, either

417 should have a discernable impact on the observed ratio for modern trees of 0.70917. For

418 example, using a value of 0.71788 for Saharan dust (Bataille et al., 2012:7), a contribution

419 of only $0.5 \%$ would raise the ${ }^{87} \mathrm{Sr} /{ }^{86} \mathrm{Sr}$ ratio by over four standard deviations above the

420 average of 0.70917 obtained for trees growing in the Bahamas/TCI in this project.

422 As might be expected given the striking homogeneity of our dataset, no convincing

423 evidence could be found for even slight effects of Saharan dust or volcanic ashfalls on

424 islands with greater summer dust-carrying rainfall, in 'inland' versus coastal locations, in

425 different topographic positions, or on different soils, including a small number growing on

426 lateritic 'red soils' (Figure 5). The only statistically significant difference that was observed

427 relates to the greater variability in ${ }^{87} \mathrm{Sr} /{ }^{86} \mathrm{Sr}$ ratios on TCI compare to the Bahamas. While it

428 is conceivable that a small amount of volcanic ashfall is responsible for the lower ratios, we

429 find this improbable based on previous studies addressing this issue (Muhs et al., 2007).

430 Alternatively, it may be that these particular trees were growing on soils derived in part

431 from middle Pleistocene deposits with lower ${ }^{87} \mathrm{Sr} /{ }^{86} \mathrm{Sr}$ ratios (Hodell et al., 1990; Kindler et

432 al., 2011). Unfortunately, as noted above, we have no detailed geological maps for TCI and

433 thus are unable at present to address this matter further. Furthermore, detailed surficial

434 geological mapping on the Bahamas, and by extension TCI, is extremely difficult due to the

435 spatial patchiness of original deposition and subsequent uneven erosion (Carew and

436 Mylroie, 1992). At the upper end of the ${ }^{87} \mathrm{Sr} /{ }^{86} \mathrm{Sr}$ range, there are only two samples more

437 than two standard deviations above the mean, which is in keeping with what would be

438 expected from measurement error alone given our sample size. There is no need, therefore,

439 to invoke any impact of Saharan dust to explain these outliers. 
441 The results reported here for 91 modern trees fall well outside the predicted range of $442{ }^{87} \mathrm{Sr} /{ }^{86} \mathrm{Sr}$ ratios $(0.70937-0.71030)$ for the Bahamas and Turks and Caicos Islands from

443 Bataille et al. (2012; Fig. 5B, raster dataset available from waterisotopes.org, Bowen, 2017)

444 (Figures 7 and 8). The predicted values are based on a three-source mixing model, which

445 takes into account weighted inputs from bedrock weathering, atmospheric mineral dust,

446 and sea salt. Whilst the weighting of the inputs varies spatially, the ${ }^{87} \mathrm{Sr} /{ }^{86} \mathrm{Sr}$ ratios for

447 bedrock (0.7080 - Bataille and Bowen, 2012), mineral dust (0.71788 - the mean of mineral

448 dust collected over the Caribbean region from Grousset and Biscaye, 2005 and Formenti et

449 al., 2011) and sea salt (0.7092 - the mean of bulk seawater) are constant. The value of

$450 \quad 0.7080$ used for bedrock in the model is based on the U.S. Geological Survey map of the

451 Caribbean region (French and Schenk, 2004), which characterizes the surface geology of

452 the Bahamas and Turks and Caicos Islands as 'Quaternary alluvium', and is given this ratio

453 using the analogous descriptor from Bataille and Bowen (2012). However, this ratio is

454 inappropriate for the islands' late Quaternary marine carbonate bedrock with a value to

455 four decimals of 0.7092.

456

457 Given the erroneously low ${ }^{87} \mathrm{Sr} /{ }^{86} \mathrm{Sr}$ ratio of bedrock and the equivalence of ratios for sea

458 salt and plant samples in the present study, the model significantly overestimates the input

459 of mineral dust. The potential sources of error in the predicted Sr isoscape for the circum-

460 Caribbean region, not least those resulting from the resolution of the surface geology

461 database and the uncertainties of modeling aerosol deposition, are acknowledged by

462 Bataille et al. (2012), who were exploring large-scale regional patterning and so were

463 primarily interested in modeling broad trends. $\mathrm{No}^{87} \mathrm{Sr} /{ }^{86} \mathrm{Sr}$ measurements were available

464 for the Bahamas and Turks and Caicos Islands to validate their model at the time. Even at

465 the broad scale at which it is intended to apply, the measured ratios for plant samples in 
the present study indicate that the model is a poor fit for the Bahamian archipelago. That the predicted range of $0.709-0.710$ actually encompasses our observed value of 0.70917 is fortuitous given the use of an inappropriate bedrock value of 0.7080 . Substituting a more accurate ${ }^{87} \mathrm{Sr} /{ }^{86} \mathrm{Sr}$ bedrock ratio of 0.7092 would have resulted in even higher predicted ratios for our study area, far above what was observed.

The recent publication of a Sr isoscape for Trinidad and Tobago, again based on measurements of modern trees (Ostapkowicz et al., 2017: Fig. 11), provides an additional test of the predictions made in Bataille et al.'s (2012; cf. Laffoon et al., 2016) model. We focus here on Tobago, since it has a simpler geology, being part of a Cretaceous volcanic arc, with a zone of Pleistocene marine deposits confined to the south of the island (Frost and Snoke, 1989; French and Schenk, 2004). Moreover, the bedrock ${ }^{87} \mathrm{Sr} /{ }^{86} \mathrm{Sr}$ values for the volcanic arc are low (0.7038 $\pm 0.0005 ; n=18$ ) (data from Frost and Snoke, 1989: Tab. 3), so that any influence of Saharan dust should be readily apparent. In this case there does appear to be a significant impact from marine sources (sea-spray and precipitation) and/or Saharan dust (bioavailable ${ }^{87} \mathrm{Sr} /{ }^{86} \mathrm{Sr}$ excluding the limestone region: $0.7058 \pm 0.0010, \mathrm{n}=$ 17; data from Ostapkowicz et al., 2017: Tab. 3). The predicted ratios of between 0.7049 and 0.7096 for Tobago in Ostapkowicz et al.'s (2017) new isoscape (with the high end of this

484 range confined to the Pleistocene marine deposits of the southwest end of the island) are at 485 the lower end of the range predicted by Bataille et al.'s model (0.7038 to 0.7129, with the 486 low values restricted to a very small part of the island) (2012; Fig. 5B, raster 487 dataset available from waterisotopes.org, Bowen, 2017) (Figure 9). This is particularly 488 noteworthy in that the bedrock geology across most of Tobago is much more resistant to weathering than marine carbonates, and so a correspondingly greater contribution from 490 allochthonous sources would be expected (Bataille et al., 2012: Fig. 6B). 
492 Accepting that Saharan dust contributes significantly to the soils of the Bahamas/TCI, why

493 do we not see any impact on strontium isotope ratios in the biosphere? Bataille et al.

494 (2012) emphasize the importance of taking airborne mineral dust into account, but note

495 that its contribution is variable across the circum-Caribbean, decreasing from east to west,

496 and is also dependent on the bedrock substrate of the island in question, in relation to both

497 its susceptibility to erosion and the amount of $\mathrm{Sr}$ it contains. While the marine carbonates

498 of the Antilles and the Bahamian archipelago can be characterized as highly weatherable,

499 they leave little material behind when they enter solution, and simply wash away (Borg

500 and Banner, 1996). This is why researchers emphasize the difficulty of developing soils on

501 limestone islands, since they contain relatively few other minerals besides $\mathrm{CaCO}_{3}$. However,

502 they are Sr-rich, and so will contribute in an ongoing fashion to the pool of biologically

503 available Sr on the islands.

504

505 Central to the discussion is not only the relative Sr concentrations in limestone and in

506 Saharan dust, and their respective ${ }^{87} \mathrm{Sr} /{ }^{86} \mathrm{Sr}$ ratios, but also the bioavailability of Sr. As

507 already noted, the ${ }^{87} \mathrm{Sr} /{ }^{86} \mathrm{Sr}$ value of late Quaternary deposits in the Bahamian archipelago

508 is tightly constrained to $\sim 0.7092$. Carbonates have some of the highest $\mathrm{Sr}$ concentrations

509 found in rock, on the order of 610 ppm (Faure, 1986; Capo et al., 1998). The Sr

510 concentration of Saharan dust has been variously reported as being from one-half (286

$511 \pm 58$ ppm; Grousset et al., 1992) to one-third of this (195 ppm; Rognon et al., 1996;

512 Grousset and Biscaye, 2005). The more recent latter figure is used in Bataille et al.'s

513 (2012:7) isoscape model. Saharan dust is highly radiogenic in a Caribbean context, with an $514 \quad{ }^{87} \mathrm{Sr} /{ }^{86} \mathrm{Sr}$ value of ca. 0.71788 (Grousset and Biscaye, 1989; 2005; Grousset et al., 1992;

515 Formenti et al., 2011). However, this refers to the bulk measurement of airborne dust 
particles, much of which (>70\%) will take the form of the clay minerals mica-illite and

517 kaolinite with decreasing amounts of quartz with distance from the source (Glaccum and

518 Prospero, 1980; see also Caquineau et al., 2002). Strontium associated with mica and

519 especially quartz will not be readily bioavailable due to the relatively low solubility of these

520 minerals (Rummel et al., 2010:892). Concentrations of highly soluble calcite, on the other

521 hand, were found to be a minor component at consistently less than $10 \%$ (Glaccum and

522 Prospero, 1980). Aarons et al. (2013: Fig. 2) separated the soluble and insoluble fractions

523 for ${ }^{87} \mathrm{Sr} /{ }^{86} \mathrm{Sr}$ measurements of Saharan dust collected in a North Atlantic transect. They

524 found that the soluble fraction was invariably less radiogenic (0.7108) than the insoluble

525 silicate fraction (0.7159), attributing this to the former's dilution with sea-salt,

526 unsurprising given the use of shipboard collection filters. The point to be made here is that

527 the dust included strontium in its insoluble fraction, which would not be readily

528 bioavailable.

530 Thus, the bioavailability of Sr in Saharan dust is unclear. As noted above, $\mathrm{Sr}^{2+}$ will be

531 adsorbed onto negatively charged clay minerals and organic matter (Capo et al., 1998). In

532 this sense Sr would be held in the soil, but once adsorbed it would need to desorb as part of

533 the soil exchange process before becoming available to be taken up by plant roots. Studies

534 have shown that both clay and organic matter inhibit the transfer of soil Sr to plants (Baes

535 et al., 1986; Lembrechts, 1993). Other complicating factors include the presence of

536 competing ions in the soil (e.g., $\mathrm{Na}^{2+}$ ), the concentration ratio of Sr to other micro- and

537 macro-nutrients, and microenvironments (including ion depletion) created in the rooting

538 zone by the plants themselves, all of which combine to render the concept of

539 'bioavailability' difficult to operationalize within a given context (Ehlken and Kirchner, 
2002). To this can be added the relationship between the timing of dustfall and the growing

541 season.

543 The empirical results presented in this paper differ substantially from the predictions

544 made by the current Sr isotope model for the Caribbean, which, while noting the

545 dominance of bedrock weathering to the bioavailable Sr flux in carbonate regions such as

546 those of the Bahamian archipelago, nevertheless still predicts a $20-30 \%$ contribution of

547 atmospheric dust sources in the southern archipelago, decreasing to $10-20 \%$ in the north

548 (Bataille et al., 2012: Fig. 5A). Our results suggest that the contribution of airborne dust to

549 the Sr flux is considerably lower than this, and is in fact undetectable in a comparatively

550 large sample of 91 measurements. However, it is still necessary to sample a greater range

551 of terrestrial vegetation than we have done here, including grasses, before concluding that

552 there is absolutely no effect on the islands' biosphere, with the further implication of little

553 to no impact of Saharan dust on ${ }^{87} \mathrm{Sr} /{ }^{86} \mathrm{Sr}$ ratios in the biosphere in other carbonate regions

554 of the Caribbean, including Florida.

555

CONCLUSIONS

558 Our results suggest that Saharan dust does not make a significant contribution to

559 bioavailable $\mathrm{Sr}$ in the Bahamian archipelago, and that bedrock is the main driver. The

560 contribution of sea-spray is not detectable isotopically because of the near-equivalence of

561 modern ocean and late Quaternary carbonate ${ }^{87} \mathrm{Sr} /{ }^{86} \mathrm{Sr}$ ratios, though the much higher $\mathrm{Sr}$

562 concentration of the latter means that this source will be overwhelmingly dominant in any

563 case. Our results support the proposition that highly weatherable carbonate bedrock will

564 override the influence of North African dust, though the full extent of this was previously 
not clear. For the 91 trees in our study we found over an order of magnitude less influence

566 of Saharan dust than predicted by Bataille et al.'s (2012) Sr isoscape. Similarly, a Sr

567 isoscape recently created for Trinidad and Tobago (Ostapkowicz et al., 2017) suggests a

568 lower contribution of Saharan dust to Tobago's biosphere than predicted by Bataille et al.'s

569 model.

571 The impact of Saharan dust on bioavailable ${ }^{87} \mathrm{Sr} /{ }^{86} \mathrm{Sr}$ ratios in the Caribbean and elsewhere

572 needs to be revisited, potentially reducing its significance for ecological and archaeological

573 provenience studies in the biosphere and underlining the need to tailor isoscapes to

574 individual contexts (cf. Wunder 2010:251-252). The extent to which the findings in the

575 present study apply to other parts of the circum-Caribbean region and further afield would

576 benefit from further investigation. Even within the Bahamian archipelago, a study focused

577 more specifically on the 'red soils' is needed, in order to determine the extent to which

578 these soils can be distinguished isotopically from the other soils of the islands. Similarly,

579 the impact of seawater as an allochthonous input would be more appropriately

580 investigated by targeting vegetation growing on the limited exposures of early and middle

581 Pleistocene deposits. We intend to address these matters in the future.

\section{ACKNOWLEDGEMENTS}

This research was supported by a grant from the Getty Foundation and by the Max Planck

586 Institute. Many thanks to Annabell Reiner and Sven Steinbrenner for assistance with

587 strontium isotope preparation and measurement, to Richard Cant and Sherriley Strachan,

588 Chief Archivist of the National Archives of the Bahamas, for providing access to materials

589 relating to the soils of the Bahamas, and to Claire Sedgwick, Registrar, World Museum, 
590 Liverpool, for help with CITES documentation. Thanks also to Gabe Bowen for repairing the

591 links to the strontium dataset for the Caribbean used in Bataille et al. (2012). We are

592 grateful for the detailed comments made by Brooke Crowley and an anonymous reviewer

593 as well as by the journal's editor, which have greatly improved the clarity and focus of the

594 paper.

595

\section{REFERENCES}

597 Aarons, S.M., Aciego, S.M., Gleason, J.D., 2013. Variable Hf-Sr-Nd radiogenic isotopic

598 compositions in a Saharan dust storm over the Atlantic: Implications for dust flux to

599 oceans, ice sheets and the terrestrial biosphere. Chemical Geology 349-350, 18-26.

600

601 Åberg, G., Jacks, G., Wickman, T., Hamilton, P.J., 1990. Strontium isotopes in trees as an 602 indicator for calcium availability. Catena 17, 1-11.

603

604 Angino, E.E., Billings, G.K., Andersen, N., 1996. Observed variations in the strontium

605 concentration of sea water. Chemical Geology 1, 145-153.

606

607 Baes, C.F., Garten, C.T., Taylor, F.G., Witherspoon, J.P., 1986. Long-term environmental 608 problems of radioactively contaminated land. Environment International 12(5), 543-553. 609

610 Bain, D.C., Bacon, J.R., 1994. Strontium isotopes as indicators of mineral weathering in 611 catchments. Catena 22, 201-214.

612

613 Bataille, C.P., Bowen, G.J., 2012. Mapping 87Sr/86Sr variations in bedrock and water for 614 large scale provenance studies. Chemical Geology 304-305, 39-52. 
616 Bataille, C.P., Laffoon, J., Bowen, G.J., 2012. Mapping multiple source effects on the

617 strontium isotopic signatures of ecosystems from the Circum-Caribbean region. Ecosphere $6183,118$.

619

620 Bern, C.R., Townsend, A.R., Farmer, G.L., 2005. Unexpected dominance of parent-material

621 strontium in a tropical forest on highly weathered soils. Ecology 86, 626-632.

622

623 Boardman, M.R., McCartney, R.F., Eaton, M.R., 1995. Bahamian paleosols: origin, relation to 624 paleoclimate, and stratigraphic significance. In: Curran, H.A., White, B. (Eds.), Terrestrial 625 and Shallow Marine Geology of the Bahamas and Bermuda, Geological Society of America 626 Special Paper, vol. 300, pp. 33-49.

627

628 Borg, L.E., Banner, J.L., 1996. Neodymium and strontium isotopic constraints on soil 629 sources in Barbados, West Indies. Geochimica et Cosmochimica Acta 60, 4193-4206.

630

631 Bowen, G.J., 2017. Gridded maps of the isotopic composition of meteoric waters.

632 http://www.waterisotopes.org.

633

634 Bricker, O., Mackenzie, F.T., 1970. Limestones and red soils of Bermuda: discussion.

635 Geological Society of America Bulletin 81, 2523-2524.

636

637 Capo, R.C., DePaolo, D.J., 1990. Seawater strontium isotopic variations from 2.5 million 638 years ago to the present. Science 249: 51-55. 
Capo, R.C., Stewart, B.W., Chadwick, O.A., 1998. Strontium isotopes as tracers of ecosystem processes: theory and methods. Geoderma 82, 197-225.

642

643 Caquineau, S., Gaudichet, A., Gomes, L., Legrand, M., 2002. Mineralogy of Saharan dust

644 transported over northwestern tropical Atlantic Ocean in relation to source regions.

645 Journal of Geophysical Research, Atmospheres 107, AAC 4-1-AAC 4-12.

646

647 Carew, J.L., Mylroie, J.E., 1985. The Pleistocene and Holocene stratigraphy of San Salvador

648 Island, Bahamas, with reference to marine and terrestrial lithofacies at French Bay. In:

649 Curran, H.A. (Ed.), Pleistocene and Holocene Carbonate Environments on San Salvador

650 Island, Bahamas, Ft. Lauderdale, CCFL Bahamian Field Station, pp. 11-61.

651

652 Carew, J.L., Mylroie, J.E., 1995. Depositional model and stratigraphy for the Quanternary 653 geology of the Bahama Islands. In: Curran, H.A., White, B. (Eds.), Terrestrial and Shallow 654 Marine Geology of the Bahamas and Bermuda, Boulder, Geological Society of America 655 Special Paper, 300, pp. 5-32.

656

657 Carew, J.L., Mylroie, J.E., 1997. Geology of the Bahamas. In: Vacher, H.L., Quinn, T. (Eds.), 658 Geology and Hydrogeology of Carbonate Islands, Elsevier, Amsterdam, pp. 91-139.

659

660 Chen, J.H., Curran, H.A., White, B., Wasserburg, G.J., 1991. Precise chronology of the last 661 interglacial period: 234U-230Th data from fossil coral reefs in the Bahamas. Geological 662 Society of America Bulletin 103(1), 82-97.

664 Colarco, P.R., Toon, O.B., Holben, B.N., 2003. Saharan dust transport to the Caribbean during 
665

666

667

668

669

670

671

672

673

674

675

676

677

678

679

680

681

682

683

684

685

686

687

688

PRIDE: 1. Influence of dust sources and removal mechanisms on the timing and magnitude of downwind aerosol optical depth events from simulations of in situ and remote sensing observations. Journal of Geophysical Research-Atmospheres 108.

Copeland, S.R., Sponheimer, M., le Roux, P.J., Grimes, V., Lee-Thorp, J.A., de Ruiter, D.J., Richards, M.P., 2008. Strontium isotope ratios $\left({ }^{87} \mathrm{Sr} /{ }^{86} \mathrm{Sr}\right)$ of tooth enamel: a comparison of solution and laser ablation multicollector inductively coupled plasma mass spectrometry methods. Rapid Communications in Mass Spectrometry 22, 3187-3194.

Correll, D.S., Correll, B., 1982. Flora of the Bahama Archipelago, including the Turks and Caicos Islands, Vaduz, A. R. Gantner Verlag.

Delany, A.C., Parkin, D.W., Griffin, J.J., Goldberg, E.D., Reimann, B.E.F., 1967. Airborne dust collected at Barbados. Geochemica et Cosmochemica Acta 31, 885-909.

Dia, A.N., Cohen, A.S., Onions, R.K., Shackleton, N.J., 1992. Seawater Sr isotope variation over the past 300Kyr and influence of global climate cycles. Nature 356, 786-788.

Ehlken, S., Kirchner, G., 2002. Environmental processes affecting plant root uptake of radioactive trace elements and variability of transfer factor data: a review. Journal of Environmental Radioactivity 58(2-3), 97-112.

689 
Faure, G., 1986. Principles of Isotope Geology. John Wiley, New York.

691

692 Fick, S.E., Hijmans, R.J., 2017. WorldClim 2: new 1-km spatial resolution climate surfaces for 693 global land areas. International Journal of Climatology 37.

694

695 Foos, A.M., 1991. Aluminous lateritic soils, Eleuthera, Bahamas: a modern analogue to 696 carbonate paleosols. Journal of Sedimentary Petrology 61, 340-348.

697

698 Foos, A.M., Bain, R.J., 1995. Mineralogy, chemistry, and petrography of soils, surface crusts,

699 and soil stones, San Salvador and Eleuthera, Bahamas. In: Curran, H.A., White, B. (Eds.), 700 Terrestrial and Shallow Marine Geology of the Bahamas and Bermuda, Geolological Society 701 of America Special Paper, 300, pp. 223-232.

702

703 Formenti, P., Schutz, L., Balkanski, Y., Desboeufs, K., Ebert, M., Kandler, K., Petzold, A., 704 Scheuvens, D., Weinbruch, S., Zhang, D., 2011. Recent progress in understanding physical 705 and chemical properties of African and Asian mineral dust. Atmospheric Chemistry and 706 Physics 11, 8231-8256.

707

708 French, C.D., Schenk, C.J., 2004. Map Showing Geology, Oil and Gas Fields, and Geologic 709 Provinces of the Caribbean Region, Geological Survey, Open-File Report 97-470-K, Central 710 Energy Resources Team, Denver.

712 Frost, C.D., Snoke, A.W., 1989. Tobago, West Indies, a fragment of a Mesozoic oceanic island 713 arc: petro-chemical evidence. Journal of the Geological Society 146, 953-964. 
715 Glaccum, R.A., Prospero, J.M., 1980. Saharan aerosols over the tropical North Atlantic716 mineralogy. Marine Geology 37, 295-321.

718 Gosz, J.R., Moore, D.I., 1989. Strontium isotope studies of atmospheric inputs to forested 719 watersheds in New Mexico. Biogeochemistry 8, 115-134.

721 Graustein, W.C., Armstrong, R.L., 1983. The use of strontium-87/strontium-86 ratios to 722 measure transport into forested watersheds. Science 219, 289-292.

724 Grousset, F.E., Biscaye, P.E., 1989. Nd and Sr isotopes as tracers of wind transport: Atlantic 725 aerosols and surface sediments. In: Leinen, M., Sarnthein, M. (Eds.), Paleoclimatology and 726 Paleometeorology: Modern and Past Patterns of Global Atmospheric Transport, Kluwer 727 Academic, Amsterdam, pp. 385-400.

Grousset, F.E., Biscaye, P.E., 2005. Tracing dust sources and transport patterns using Sr, Nd and Pb isotopes. Chemical Geology 222, 149-167.

732 Grousset, F.E., Rognon, P., Coudé-Gaussen, G., Pédemay, P., 1992. Origins of peri-Saharan

733 dust deposits traced by their Nd and Sr isotopic composition. Palaeogeography,

734 Palaeoclimatology, Palaeoecology 93, 203-212.

735

736 Hartman, G., Richards, M., 2014. Mapping and defining sources of variability in bioavailable 737 strontium isotope ratios in the Eastern Mediterranean. Geochimicha et Cosmochimica Acta 738 126, 250-254. 
740

741 stratigraphy and sea-level history. Quaternary Science Reviews 17, 333-355.

742

743

744

Hearty, P.J., Kindler, P., 1993. New perspectives on Bahamian geology: San Salvador Island, Bahamas. Journal of Coastal Research 9(2), 577-594.

745

746

747 748

749

750

751 Science Letters 128, 643-651.

752

753

754

755 101, 23389-23400.

756

757

758

759 fluxes to the oceans. Chemical Geology: Isotope Geoscience Section 80, 291-307.

760

761 Hodell, D.A., Quinn, R.L., Brenner, M., Kamenov, G., 2004. Spatial variation of strontium

762 isotopes $\left({ }^{87} \mathrm{Sr} /{ }^{86} \mathrm{Sr}\right)$ in the Maya region: a tool for tracking ancient human migration.

763 Journal of Archaeological Science 31(5), 585-601.

Hearty, P.J., Kindler, P., 1997. The stratigraphy and surficial geology of New Providence and surrounding islands, Bahamas. Journal of Coastal Research 13(3), 798-812.

Henderson, G.M., Martel, D.J., O’Nions, R.K., Shackleton, N.J., 1994. Evolution of seawater ${ }^{87} \mathrm{Sr} /{ }^{86} \mathrm{Sr}$ over the last $400 \mathrm{ka}$ : the absence of glacial/interglacial cycles. Earth and Planetary

Herwitz, S.R., Muhs, D.R., Prospero, J.M. and Vaughn, B. 1996. Origins of Bermuda's clay-rich paleosols and their climatic significance. Journal of Geophysical Research-Atmospheres Hodell, D.A., Mead, G.A., Mueller, P.A., 1990. Variation in the strontium isotopic composition of seawater (8 Ma to present): Implications for chemical weathering rates and dissolved 
765 Kamenov, G.D., Brenner, M., Tucker, J.L., 2009. Anthropogenic versus natural control on

766 trace element and $\mathrm{Sr}-\mathrm{Nd}-\mathrm{Pb}$ isotope stratigraphy in peat sediments of southeast Florida

767 (USA), 1500 AD to present. Geochimica et Cosmochimica Acta 73, 3549-3567.

768

769 Kaufman, Y.J., Koren, I., Remer, L.A., Tanré, D., Ginoux, P., Fan, S., 2005. Dust transport and 770 deposition observed from the Terra-Moderate Resolution Imaging Spectroradiometer 771 (MODIS) spacecraft over the Atlantic Ocean. Journal of Geophysical Research 119, D10S12.

773 Kennedy, M.J., Chadwick, O.A., Vitousek, P.M., Derry, L.A., Hendricks, D.M., 1998. Changing 774 sources of base cations during ecosystem development, Hawaiian Islands. Geology 26, $775 \quad 1015-1018$.

776

777 Kindler, P., Godefroid, F., Chiaradia, M., Ehlert, C., Eisenhauer, A., Frank, M., Hasler, C.-A., 778 Samankassou, E., 2011. Discovery of Miocene to early Pleistocene deposits of Mayaguana, 779 Bahamas. Geology 39, 986-979.

Kroma, M.D., Cliff, R.A., Eijsink, L.M., Herut, B., Chester, R., 1999. The characterisation of

Saharan dusts and Nile particulate matter in surface sediments from the Levantine basin

783 using Sr isotopes. Marine Geology 155, 319-330.

784

Kuznetsov, A.B., Semikhatov, M.A., Gorokhov, I.M., 2012. The Sr isotope composition of the world ocean, marginal and inland seas: Implications for the Sr isotope stratigraphy.

787 Stratigraphy and Geological Correlation 20(6), 501-515.

789 Laffoon, J.E., Davies, G.R., Hoogland, M.L.P., Hofman, C.L., 2012. Spatial variation of 
790 biologically available strontium isotopes (87Sr/86Sr) in an archipelagic setting: a case

791 study from the Caribbean. Journal of Archaeological Science 39, 2371-2384.

792

793 Laffoon, J.E., Hoogland, M.L.P., 2012. Migration and mobility in the circum-Caribbean:

794 Integrating archaeology and isotopic analysis. In: Kaiser, E., Burger, J., Schier, W. (Eds.),

795 Population Dynamics in Prehistory and Early History: New Approaches Using Stable

796 Isotopes and Genetics, Amsterdam, de Gruyter, pp. 337-353.

797

798 Laffoon, J.E., Rodríguez Ramos, R., Chanlatte Baik, L., Storde, Y.N., Rodríguez Lopez, M.,

799 Davies, G.R., Hofman, C.L., 2014. Long-distance exchange in the precolonial Circum-

800 Caribbean: A multi-isotope study of animal tooth pendants from Puerto Rico. Journal of

801 Anthropological Archaeology 35, 220-233.

802

803 Laffoon, J.E., Sonnemann, T.F., Antczak, M.M., Antczak, A., 2016. Sourcing nonnative

804 mammal remains from Dos Mosquises Island, Venezuela: new multiple isotope evidence.

805 Archaeological and Anthropological Sciences, doi: 10.1007/s12520-016-0453-6.

806

807 Laffoon, J.E., Sonnemann, T.F., Shafie, T., Hofman, C.L., Brandes, U., Davies, G.R., 2017.

808 Investigating human geographic origins using dual-isotope $\left({ }^{87} \mathrm{Sr} /{ }^{86} \mathrm{Sr}, \delta^{18} 0\right)$ assignment 809 approaches. PLoS ONE 12(2), e0172562.

810

811 Lehnert, K., Su, Y., Langmuir, C.H., Sarbas, B., Nohl, U., 2000. A global geochemical database

812 structure for rocks. Geochemistry Geophysics Geosystems 1. doi: 10.1029/1999GC000026 813

814 Lembrechts, J., 1993. A review of literature on the effectiveness of chemical amendments in 
815 reducing the soil-to-plant transfer of radiostrontium and radiocesium. Science of the Total 816 Environment 137(1-3), 81-98.

817

818 Little, B.G., Buckley, D.K., Cant, R., Henry, P.W.T., Jefferies, A., Mather, J.D., Stark, J., Young, 819 R.N., 1977. The Land Resources of the Bahamas: A Summary. Land Resources Division, 820 Ministry of Overseas Development, Study 27.

821

822 Lovett, G.M., Lindberg, S.E., 1984. Dry deposition and canopy exchange in a mixed oak 823 forest as determined by analysis of throughfall. Journal of Applied Ecology 21, 1013-1027. 824

825 McArthur, J.M., 1994. Recent trends in strontium isotope stratigraphy. Terra Nova 6, 331826358.

827

828 Montgomery, J., Evans, J.A., Neighbour, T., 2003. Sr isotope evidence for population 829 movement within the Hebridean Norse community of NW Scotland. Journal of the 830 Geological Society, London 160, 649-653.

831

832 Mooney, C.N., 1905. Soils of the Bahama Islands. In: Shattuck, G.B. (Ed.), The Bahama 833 Islands, Macmillan, New York, pp. 147-184.

834

835 Muhs, D.R., Budahn, J.R., Prospero, J.M., Carey, S.N., 2007. Geochemical evidence for African 836 dust inputs to soils of western Atlantic islands: Barbados, the Bahamas, and Florida. Journal 837 of Geophysical Research: Earth Surface, 112. doi: 10.1029/2005JF000445. 838

839 Muhs, D.R., Bush, C.A., Stewart, K.C., Rowland, T.R., Crittenden, R.C., 1990. Geochemical 
840

841

842

843

844 845

846

847

848

849

850

851

852

853

854

855

856

857

858

859

860

861

862 Ostapkowicz, J., Bronk Ramsey, C., Brock, F., Cartwright, C.R., Stacey, R., Richards, M., 2013.

863 Birdmen, cemís and duhos: material studies and AMS ${ }^{14} \mathrm{C}$ dating of Pre-Hispanic Caribbean

864 wood sculptures in the British Museum. Journal of Archaeological Science 40, 4675-4687.

evidence of Saharan dust parent material for soils developed on Quaternary limestones of Caribbean and Western Atlantic islands. Quaternary Research 33, 157-177.

Muhs, D.R., Crittenden, R.C., Rosholt, J.N., Bush, C.A., Stewart, K.C., 1987. Genesis of marine terrace soils, Barbados, West Indies: Evidence from mineralogy and geochemistry. Earth Surface Processes and Landforms 12, 605-618.

Mylroie, J.E., Carew, J.L., 1995. Geology and karst geomorphology of San Salvador Island, Bahamas. Carbonates and Evaporites 10(2), 193-206.

Nowottnick, E., Colarco, P., da Silva, A., Hlavka, D., McGill, M., 2011. The fate of Saharan dust across the Atlantic and implications for a Central American dust barrier. Atmospheric Chemistry and Physics 11, 8415-8431.

Ostapkowicz, J., 2015. Either a piece of domestic furniture of the Indians or one of their Gods': the study of Lucayan duhos. Journal of Caribbean Archaeology 15, 62-66.

Ostapkowicz, J., Brock, F., Wiedenhoeft, A., Snoeck, C., Pouncett, J., Baksh-Comeau, Y., Schulting, R., Boomert, A., 2017. Black pitch, carved histories: AMS ${ }^{14}$ C, wood ID and strontium results on prehistoric wood carvings from Trinidad's Pitch Lake. Journal of Archaeological Science: Reports 16, 341-358. 
866 Ostapkowicz, J., Naqqi Manco, B., Richards, M., Wiedenhoeft, A., 2012. Hidden Stories: Trees 867 and the charting of Lucayan histories. Times of the Islands, Summer, 22-27.

868

869 Pestle, W.J., Simonetti, A., Curet, L.A., 2013. 87Sr/86Sr variability in Puerto Rico: geological 870 complexity and the study of paleomobility. Journal of Archaeological Science 40, 25618712569.

872

873 Poszwa, A., Dambrine, E., Ferry, B., Pollier, B., Loubet, M., 2002. Do deep tree roots provide 874 nutrients to the tropical rainforest? Biogeochemistry 60, 97-118.

875

876 Prognon, F., Cojan, I., Kindler, P., Thiry, M., Demange, M., 2011. Mineralogical evidence for a 877 local volcanic origin of the parent material of Bermuda Quaternary paleosols. Quaternary 878 Research 75, 256-266.

879

880 Prospero, J.M., 1999. Long-range transport of mineral dust in the global atmosphere: 881 Impact of African dust on the environment of the southeastern United States. Proceedings 882 of the National Academy of Sciences (USA) 96, 3396-3403.

883

884 Prospero, J.M., Carlson, T.N., 1972. Vertical and areal distribution of Saharan dust over 885 western equatorial North-Atlantic Ocean. Journal of Geophysical Research-Atmospheres $88677,5255-5260$.

887

888 Prospero, J.M., Glaccum, R.A., Nees, R.T., 1981. Atmospheric transport of soil dust from 889 Africa to South America. Nature 289, 570-572. 
891 Prospero, J.M., Lamb, P.J., 2003. African droughts and dust transport to the Caribbean:

892 climate change implications. Science 302, 1024- 1027.

893

894 Prospero, J.M., Mayol-Bracero, O.L., 2013. Understanding the transport and impact of 895 African dust on the Caribbean basin. Bulletin of the American Meteorological Society 94, $896 \quad 1329-1337$.

897

898 Prospero, J.M., Nees, R.T., Uematsu, M., 1987. Deposition rate of particulate and dissolved 899 aluminum derived from Saharan dust in precipitation at Miami, Florida, Journal of 900 Geophysical Research-Atmospheres 92. 14723-14731.

901

902 Pushkar, P., Steuber, A.M., Tomblin, J.F., Julian, G.M., 1973. Strontium isotopic ratios in 903 volcanic rocks from St. Vincent and St. Lucia, Lesser Antilles. Journal of Geophysical 904 Research-Oceans 78(8), 1279-1287.

905

906 Reinhardt, E.G., Blenkinsop, J., Patterson, R.T., 1999. Assessment of a Sr isotope vital effect $907 \quad\left({ }^{87} \mathrm{Sr} /{ }^{86} \mathrm{Sr}\right)$ in marine taxa from Lee Stocking Island, Bahamas. Geo-Marine Letters 18, 241908246.

909

910 Reynolds, A.C., Betancourt, J.L., Quade, J., Patchett, P.J., Dean, J.S., Stein, J., 2005. ${ }^{87} \mathrm{Sr} /{ }^{86} \mathrm{Sr}$ 911 sourcing of ponderosa pine used in Anasazi great house construction at Chaco Canyon, New 912 Mexico. Journal of Archaeological Science 32, 1061-1075.

914 Reynolds, A.C., Quade, J., Betancourt, J.L., 2012. Strontium isotopes and nutrient sourcing in 
915

a semi-arid woodland. Geoderma 189-190, 574-584.

916

917

918

919

920

921 Rognon, P., Coudé-Gaussen, G., Revel, M., Grousset, F.E., Pedemay, P., 1996. Holocene

922 Saharan dust deposition on the Cape Verde Islands: sedimentological and Nd-Sr isotopic

923 evidence. Sedimentology 43, 359-366.

924

925

926

927

928

929

930

931

932

933

934

935

936

937

938

939 Snoeck, C., 2014. Impact of strontium sea spray effect on the isotopic ratio $\left({ }^{87} \mathrm{Sr} /{ }^{86} \mathrm{Sr}\right)$ of

940 plants in coastal Ireland. Quaternary Newsletter 134, 37-39. 
942 Snoeck, C., Pouncett, J., Ramsey, G., Meighan, I.G., Mattielli, N., Lee-Thorp, J.A., Schulting, R.J.,

943 2016. Mobility during the Neolithic and Bronze Age in Northern Ireland explored using

944 strontium isotope analysis of cremated human bone. American Journal of Physical

945 Anthropology 160, 397-413.

946

947 Syers, J.K., Jackson, M.L., Berkheiser, V.E., Clayton, R.N., Rex, R.W., 1969. Eolian sediment

948 influence on pedogenesis during the Quaternary. Soil Science 107, 421-427.

949

950 Vitousek, P.M., Kennedy, M.J., Derry, L.A., Chadwick, O.A., 1999. Weathering versus

951 atmospheric sources of strontium in ecosystems on young volcanic soils. Oecologia 121,

$952 \quad 255-259$.

953

954 Wanless, H.R., Dravis, J.J., Tedesco, L.P., Rossinsky, V. 1989. Carbonate Environments and

955 Sequences of Caicos Platform, Field Trip Guidebook T374. American Geophysical Union,

956 Washington, D.C.

957

958 Whipkey, C.E., Capo, R.C., Chadwick, O.A., Stewart, B.W., 2000. The importance of sea spray

959 to the cation budget of a coastal Hawaiian soil: a strontium isotope approach. Chemical

960 Geology 168, 37-48.

961

962 Whitaker, F.F. and Smart, P.L., 1997. Hydrogeology of the Bahamian archipelago. In: Vacher,

963 H.L., Quinn, T. (Eds.), Geology and Hydrogeology of Carbonate Islands, Elsevier,

964 Amsterdam, pp. 183-216.

965 
966 Wood, J. 1996. The Geomorphological Characterisation of Digital Elevation Models. PhD

967 thesis, University of Leicester. Available at: https://lra.le.ac.uk/handle/2381/34503.

968

969 Wood, J. 2009. The Landserf Manual, version 1.0. landserf.org. Available at:

970 http://www.staff.city.ac.uk/ jwo/landserf/landserf230/doc/landserfManual.pdf.

971

972 Wunder, M., 2010. Using isoscapes to model probability surfaces for determining

973 geographic origins. In: West, J., Bowen, G., Dawson, T., Tu, K. (Eds.), Isoscapes:

974 Understanding Movement, Pattern, and Process on Earth through Isotope Mapping.

975 Springer, Dordrecht, pp. 251-270.

976

977

978 
980

981

Table $1 .{ }^{87} \mathrm{Sr} /{ }^{86} \mathrm{Sr}$ results and metadata for sampled modern trees from the Bahamas and 982 TCI.

983

984

Table 2 . Summary statistics for ${ }^{87} \mathrm{Sr} /{ }^{86} \mathrm{Sr}$ results by island.

985

986

Figure 1. Map of the study region showing the locations of islands sampled in this study.

987

Lee Stocking Island is also identified as providing ${ }^{87} \mathrm{Sr} /{ }^{86} \mathrm{Sr}$ results for various reef and

988

mangrove taxa (Reinhardt et al., 1999). Data sources: SRTM Void Filled elevation data

989

courtesy of the U.S. Geology Survey and The GEBCO_2014 Grid, version 20150318,

990

www.gebco.net.

991

992

Figure 2. Percentage of annual precipitation for: a) summer; and b) winter. Data sources:

993 WorldClim Version 2 (Fick and Hijmans, 2017) and The GEBCO_2014 Grid, version

994 20150318, www.gebco.net.

995

996 Figure 3. The distribution of the main soils and sample locations for: a) Cat Island; and b)

997 Long Island. Data sources: Soils of the Bahama Islands (Mooney, 1905) and The

998 GEBCO_2014 Grid, version 20150318, www.gebco.net.

999

1000 Figure 4. Caicos Islands, Turks and Caicos, showing sample locations. Sampling on North,

1001 Middle and East Caicos is concentrated along the north coasts due to the absence of trees

1002 on the swampland and tidal flats of the southern half of the islands. Data sources: The

1003 GEBCO_2014 Grid, version 20150318, www.gebco.net. 
1005 Figure 5a) small Swietenia mahagoni growing on flooded 'Bahama Black Loam', south of

1006 Old Bight, Cat Island (C7); b) medium Swietenia mahagoni growing on 'Coral Sand',

1007 Hamilton's, Long Island (L7); c) medium Guaiacum sanctum growing on yellow-brown

1008 loam, Lorimer's, Middle Caicos (M7); d) small Guaiacum sanctum bush growing on shallow

1009 'Bahama Red Loam', south of Scrub Hill, Long Island (L6).

1010

1011 Figure 6. Box plot (central horizontal line = median; shaded box = interquartile range

1012 (IQR); whiskers = $1.5 \times \mathrm{IQR}$ ) of the 87Sr/86Sr ratios from the Bahamas and TCI. Created in

1013 BoxPlotR (Spitzer et al., 2014).

1014

1015 Figure 7. Predicted Sr isotope rations for the circum-Caribbean region from the three-

1016 source mixing model (after Bataille et al., 2012, Figure 5B). Data sources: Circum-

1017 Caribbean Sr isotopes (Bowen, 2017; Lehnert et al., 2000) and The GEBCO_2014 Grid,

1018 version 20150318, www.gebco.net.

1019

1020 Figure 8. Histograms showing the difference between the modelled ${ }^{87} \mathrm{Sr} /{ }^{86} \mathrm{Sr}$ isotope ratios

1021 for the Bahamian archipelago from Bataille et al. (2012), based on a three-source mixing

1022 model which over-estimates the contribution of Saharan dust, and the results obtained on

1023 modern trees in this paper.

1024

1025 Figure 9. Histograms showing the difference between the modelled ${ }^{87} \mathrm{Sr} /{ }^{86} \mathrm{Sr}$ isotope ratios

1026 for Tobago from Bataille et al. (2012), based on a three-source mixing model which over-

1027 estimates the contribution of Saharan dust, and Ostapkowicz et al. (2017), based on

1028 Empirical Bayesian Kriging of measured values from modern plant samples. 
Island Eleuthera Eleuthera Long Island Long Island Long Island Long Island Long Island Long Island Long Island Long Island Long Island Long Island Long Island Long Island Long Island Long Island Long Island Long Island Long Island Long Island Long Island Long Island Cat Island Cat Island Cat Island Cat Island Cat Island Cat Island Cat Island Cat Island Cat Island Cat Island Cat Island
Group Species Bahamas Guaiacum sanctum Bahamas Guaiacum sanctum Bahamas Guaiacum sanctum Bahamas Guaiacum sanctum Bahamas Guaiacum sanctum Bahamas Guaiacum sanctum Bahamas Guaiacum sanctum Bahamas Guaiacum sanctum Bahamas Swietenia mahagoni Bahamas Swietenia mahagoni Bahamas Guaiacum sanctum Bahamas Swietenia mahagoni Bahamas Guaiacum sanctum Bahamas Guaiacum sanctum Bahamas Swietenia mahagoni Bahamas Guaiacum sanctum Bahamas Swietenia mahagoni Bahamas Guaiacum sanctum Bahamas Swietenia mahagoni Bahamas Guaiacum sanctum Bahamas Guaiacum sanctum Bahamas Guaiacum sanctum Bahamas Swietenia mahagoni Bahamas Swietenia mahagoni Bahamas Swietenia mahagoni Bahamas Swietenia mahagoni Bahamas Swietenia mahagoni Bahamas Swietenia mahagoni Bahamas Swietenia mahagoni Bahamas Swietenia mahagoni Bahamas Guaiacum sanctum Bahamas Swietenia mahagoni Bahamas Guaiacum sanctum
Map Sample id ${ }^{87} \mathrm{Sr} /{ }^{86} \mathrm{Sr}$ Z-sco 09-001 09-002 L1 09-003 L2 09-004 L3 09-005 L4 09-006 L5 09-007 L6 09-008 L7 09-009 L8 09-010 L9 09-011 L10 09-012 L11 09-013

L12 09-014 L13 09-015

L14 09-016

L15 09-017

L16 09-018

L17 09-019

L18 09-020

L19 09-021

L20 09-022

C1 09-023

C2 09-024

C3 09-025

C4 09-026

C5 09-027

C6 09-028

C7 09-029

C8 09-030

C9 09-031

C10 09-032

C11 09-033

$\begin{array}{rrrrrr}0.709183 & -1.457 & - & - & - & - \\ 0.709155 & 1.319 & - & - & - & -\end{array}$

1.319

$\begin{array}{lllllll}0.709175 & -0.621 & 22.87478 & -74.86753 & 10 & \mathrm{med}\end{array}$

$\begin{array}{lllllll}0.709170 & -0.142 & 22.92033 & -74.88619 & 5 & \text { large }\end{array}$

$\begin{array}{lllllll}0.709169 & -0.069 & 23.00236 & -74.88794 & 9 & \text { small }\end{array}$

$\begin{array}{llllll}0.709169 & -0.038 & 23.06525 & -74.92806 & 8 & \text { small }\end{array}$

$\begin{array}{lllllll}0.709164 & 0.429 & 23.09194 & -75.12017 & 18 & \text { large }\end{array}$

$\begin{array}{llllll}0.709173 & -0.412 & 23.09689 & -75.02117 & 9 & \text { med }\end{array}$

$\begin{array}{lllllll}0.709157 & 1.166 & 23.12081 & -75.05281 & 7 & \text { med }\end{array}$

$\begin{array}{llllll}0.709169 & -0.061 & 23.17117 & -75.10114 & 6 & \text { med }\end{array}$

$\begin{array}{lllllll}0.709159 & 0.962 & 23.20539 & -75.10681 & 9 & \text { med }\end{array}$

$\begin{array}{llllll}0.709163 & 0.580 & 23.25233 & -75.10308 \quad 4 & \text { med }\end{array}$

$\begin{array}{llllll}0.709181 & -1.229 & 23.28922 & -75.10383 & 12 & \text { med }\end{array}$

$\begin{array}{lllllll}0.709162 & 0.632 & 23.33389 & -75.11992 & 11 & \text { small }\end{array}$

$\begin{array}{lllllll}0.709171 & -0.237 & 23.38131 & -75.14369 & 8 & \text { med }\end{array}$

$\begin{array}{lllllll}0.709160 & 0.824 & 23.66547 & -75.31228 & 7 & \text { small }\end{array}$

$\begin{array}{llllll}0.709180 & -1.127 & 23.62439 & -75.29589 & 2 & \text { med }\end{array}$

$\begin{array}{lllllll}0.709157 & 1.165 & 23.55958 & -75.25328 & 5 & \text { large }\end{array}$

$\begin{array}{lllllll}0.709164 & 0.475 & 23.55603 & -75.25703 & 3 & \text { med }\end{array}$

$\begin{array}{lllllll}0.709185 & -1.576 & 23.52136 & -75.24961 & 11 & \text { large }\end{array}$

$\begin{array}{lllllll}0.709173 & -0.433 & 23.45231 & -75.21642 & 6 & \text { med }\end{array}$

$\begin{array}{lllllll}0.709170 & -0.166 & 23.41817 & -75.18603 & 8 & \text { large }\end{array}$

$\begin{array}{lllllll}0.709167 & 0.166 & 24.60456 & -75.65319 & 0 & \text { small }\end{array}$

$\begin{array}{lllllll}0.709166 & 0.264 & 24.52508 & -75.59486 & 1 & \text { small }\end{array}$

$\begin{array}{llllll}0.709171 & -0.211 & 24.45044 & -75.54706 & 5 & \text { med }\end{array}$

$\begin{array}{lllllll}0.709179 & -1.014 & 24.34486 & -75.48083 & 10 & \text { med }\end{array}$

$\begin{array}{lllllll}0.709175 & -0.643 & 24.27172 & -75.40336 & 7 & \text { small }\end{array}$

$\begin{array}{lllllll}0.709177 & -0.852 & 24.20833 & -75.38653 & 4 & \text { small }\end{array}$

$\begin{array}{lllllll}0.709166 & 0.316 & 24.16467 & -75.40558 & 3 & \text { small }\end{array}$

$\begin{array}{lllllll}0.709168 & 0.120 & 24.14136 & -75.45728 & 7 & \text { small }\end{array}$

$\begin{array}{lllllll}0.709169 & -0.024 & 24.14333 & -75.43706 & 21 & \text { small }\end{array}$

$\begin{array}{lllllll}0.709177 & -0.816 & 24.18242 & -75.31803 & 12 & \text { med }\end{array}$

$\begin{array}{lllllll}0.709166 & 0.261 & 24.17364 & -75.31592 & 19 & \text { small }\end{array}$
-

inland Coral Plane

inland Swamp Plane

inland Red Plane

coastal Coral Ridge

inland Red Plane

coastal Coral Plane

inland Black Plane

inland Black Plane

coastal Black Plane

inland Black Plane

coastal Black Plane

coastal Black Plane

inland Black Plane

coastal Coral Plane

coastal Black Plane

inland Black Plane

inland Black Ridge

inland Coral Plane

coastal Black Plane

coastal Red Plane

coastal Black Plane

coastal Red Plane

coastal Black Plane

coastal Black Plane

inland Swamp Plane

inland Black Plane

inland Black Plane

coastal Black Ridge

inland Coral Ridge

inland Coral Ridge 


\begin{tabular}{|c|c|c|c|c|c|c|c|c|c|c|c|c|c|}
\hline Cat Island & Bahamas & Guaiacum sanctum & C12 & $09-034$ & 0.709171 & -0.252 & 24.17492 & -75.31669 & 23 & med & inland & Coral & Ridge \\
\hline Cat Island & Bahamas & Guaiacum sanctum & $\mathrm{C} 13$ & 09-035 & 0.709174 & -0.541 & 24.19692 & -75.33981 & 13 & med & inland & Black & Plane \\
\hline Cat Island & Bahamas & Swietenia mahagoni & C14 & 09-036 & 0.709174 & -0.492 & 24.21947 & -75.35556 & 20 & small & inland & Red & Channel \\
\hline Cat Island & Bahamas & Lysiloma latisiliquum & C15 & 09-037 & 0.709176 & -0.768 & 24.17492 & -75.31669 & 23 & large & inland & Coral & Ridge \\
\hline Providenciales & TCI & Guaiacum officinale & - & BNM 412 & 0.709166 & 0.245 & - & - & - & - & - & - & - \\
\hline Providenciales & $\mathrm{TCI}$ & Guaiacum sanctum & P1 & BNM 419 & 0.709174 & -0.539 & 21.79413 & -72.17587 & 8 & large & coastal & & Plane \\
\hline Providenciales & $\mathrm{TCI}$ & Zanthoxylum flavum & P2 & BNM 420 & 0.709166 & 0.244 & 21.79413 & -72.17587 & 8 & med & coastal & & Plane \\
\hline Providenciales & TCI & Swietenia mahagoni & P3 & BNM 421 & 0.709158 & 1.045 & 21.83880 & -72.32998 & 9 & large & coastal & & Plane \\
\hline Providenciales & TCI & Guaiacum sanctum & P4 & BNM 422 & 0.709198 & -2.912 & 21.83880 & -72.32998 & 9 & small & coastal & & Plane \\
\hline Providenciales & TCI & Guaiacum sanctum & P5 & BNM 423 & 0.709171 & -0.201 & 21.81352 & -72.28062 & 8 & large & coastal & & Plane \\
\hline Providenciales & TCI & Guaiacum sanctum & P6 & BNM 424 & 0.709162 & 0.630 & 21.74917 & -72.26825 & 7 & small & coastal & & Plane \\
\hline Providenciales & TCI & Zanthoxylum flavum & P7 & BNM 425 & 0.709174 & -0.491 & 21.77740 & -72.17172 & 20 & med & coastal & & Ridge \\
\hline Providenciales & TCI & Guaiacum sanctum & P8 & BNM 426 & 0.709163 & 0.555 & 21.76381 & -72.17104 & 20 & med & coastal & & Ridge \\
\hline Providenciales & $\mathrm{TCI}$ & Guaiacum sanctum & P9 & BNM 427 & 0.709161 & 0.775 & 21.76381 & -72.17104 & 20 & med & coastal & & idge \\
\hline Providenciales & TCI & Swietenia mahagoni & $\mathrm{P} 10$ & BNM 428 & 0.709164 & 0.456 & 21.78672 & -72.16900 & 7 & large & coastal & & Plane \\
\hline Providenciales & TCI & Guaiacum sanctum & P11 & BNM 429 & 0.709149 & 1.955 & 21.78042 & -72.25175 & 14 & large & coastal & & Plane \\
\hline North Caicos & TCI & Swietenia mahagoni & $\mathrm{N} 1$ & BNM 444 & 0.709167 & 0.172 & 21.83683 & -71.88733 & 6 & small & inland & & Plane \\
\hline North Caicos & TCI & Swietenia mahagoni & N2 & BNM 445 & 0.709135 & 3.332 & 21.83783 & -71.90117 & 7 & small & inland & & Plane \\
\hline North Caicos & TCI & Guaiacum sanctum & N3 & BNM 446 & 0.709175 & -0.641 & 21.89217 & -71.92083 & 7 & large & coastal & & Plane \\
\hline North Caicos & TCI & Guaiacum sanctum & N4 & BNM 447 & 0.709165 & 0.381 & 21.93700 & -72.03750 & 7 & med & coastal & & Plane \\
\hline North Caicos & TCI & Cordia sebestina & N5 & BNM 448 & 0.709187 & -1.838 & 21.93717 & -72.03717 & 8 & med & coastal & & Plane \\
\hline North Caicos & $\mathrm{TCI}$ & Guaiacum sanctum & N6 & BNM 449 & 0.709162 & 0.639 & 21.93717 & -72.03650 & 8 & large & inland & & Plane \\
\hline North Caicos & TCI & Swietenia mahagoni & N7 & BNM 450 & 0.709171 & -0.270 & 21.93683 & -72.02200 & 11 & med & inland & & Channel \\
\hline North Caicos & TCI & Swietenia mahagoni & N8 & BNM 451 & 0.709182 & -1.279 & 21.92467 & -71.98750 & 10 & large & coastal & & Plane \\
\hline North Caicos & TCI & Guaiacum sanctum & N9 & BNM 452 & 0.709162 & 0.651 & 21.93170 & -71.97722 & 11 & small & inland & & Plane \\
\hline North Caicos & TCI & Swietenia mahagoni & N10 & BNM 453 & 0.709168 & 0.056 & 21.93170 & -71.97722 & 7 & large & inland & & Channel \\
\hline North Caicos & TCI & Guaiacum sanctum & N11 & BNM 454 & 0.709177 & -0.789 & 21.92037 & -71.92178 & 9 & small & inland & & Plane \\
\hline North Caicos & $\mathrm{TCI}$ & Guaiacum sanctum & N12 & BNM 455 & 0.709170 & -0.103 & 21.91883 & -71.92647 & 7 & large & inland & & Plane \\
\hline North Caicos & TCI & Swietenia mahagoni & N13 & BNM 456 & 0.709167 & 0.174 & 21.92183 & -71.92600 & 7 & large & inland & & Plane \\
\hline North Caicos & TCI & Swietenia mahagoni & N14 & BNM 457 & 0.709168 & 0.059 & 21.93170 & -71.97722 & 6 & med & coastal & & Plane \\
\hline North Caicos & TCI & Guaiacum sanctum & N15 & BNM 458 & 0.709162 & 0.671 & 21.94050 & -71.95133 & 6 & med & coastal & & Plane \\
\hline North Caicos & TCI & Swietenia mahagoni & N16 & BNM 459 & 0.709168 & 0.072 & 21.90550 & -72.03633 & 7 & large & coastal & & Plane \\
\hline North Caicos & TCI & Guaiacum sanctum & N17 & BNM 460 & 0.709184 & -1.497 & 21.91833 & -72.00817 & 14 & small & coastal & & Ridge \\
\hline North Caicos & TCI & Swietenia mahagoni & N18 & BNM 461 & 0.709163 & 0.610 & 21.91817 & -72.00567 & 4 & large & coastal & & Plane \\
\hline
\end{tabular}




\begin{tabular}{|c|c|c|c|c|c|c|c|c|c|c|c|c|c|}
\hline North Caicos & TCI & Swietenia mahagoni & N19 & BNM 462 & 0.709176 & -0.697 & 21.90333 & -72.00100 & 9 & large & coastal & & Plane \\
\hline North Caicos & TCI & Guaiacum sanctum & $\mathrm{N} 20$ & BNM 463 & 0.709163 & 0.588 & 21.95050 & -72.03533 & 6 & large & inland & & Plane \\
\hline North Caicos & TCI & Swietenia mahagoni & N21 & BNM 464 & 0.709165 & 0.402 & 21.95000 & -72.03467 & 11 & med & coastal & & Plane \\
\hline Middle Caicos & TCI & Zanthoxylum flavum & M1 & BNM 430 & 0.709158 & 1.101 & 21.81255 & -71.66547 & 12 & small & inland & & Plane \\
\hline Middle Caicos & TCI & Swietenia mahagoni & M2 & BNM 431 & 0.709170 & -0.159 & 21.82350 & -71.67857 & 12 & med & coastal & & Plane \\
\hline Middle Caicos & TCI & Guaiacum sanctum & M3 & BNM 432 & 0.709168 & 0.115 & 21.81933 & -71.67617 & 12 & med & coastal & & Plane \\
\hline Middle Caicos & TCI & Swietenia mahagoni & M4 & BNM 433 & 0.709163 & 0.539 & 21.81933 & -71.67617 & 6 & med & inland & & Plane \\
\hline Middle Caicos & TCI & Guaiacum sanctum & M5 & BNM 434 & 0.709154 & 1.493 & 21.81900 & -71.68450 & 11 & med & inland & & Plane \\
\hline Middle Caicos & TCI & Guaiacum sanctum & M6 & BNM 435 & 0.709176 & -0.675 & 21.81900 & -71.68417 & 13 & small & coastal & & Plane \\
\hline Middle Caicos & TCI & Guaiacum sanctum & M7 & BNM 436 & 0.709169 & -0.013 & 21.78917 & -71.68667 & 12 & med & inland & Red & Plane \\
\hline Middle Caicos & TCI & Guaiacum sanctum & M8 & BNM 437 & 0.709170 & -0.137 & 21.80700 & -71.72000 & 3 & med & inland & & Plane \\
\hline Middle Caicos & TCI & Cordia sebestina & M9 & BNM 438 & 0.709174 & -0.500 & 21.82333 & -71.73483 & 3 & large & inland & & Plane \\
\hline Middle Caicos & TCI & Swietenia mahagoni & M10 & BNM 439 & 0.709165 & 0.409 & 21.82583 & -71.77533 & 15 & med & inland & & Plane \\
\hline Middle Caicos & TCI & Swietenia mahagoni & M11 & BNM 440 & 0.709175 & -0.672 & 21.82017 & -71.77217 & 11 & large & inland & & Plane \\
\hline Middle Caicos & TCI & Swietenia mahagoni & M12 & BNM 441 & 0.709165 & 0.350 & 21.81850 & -71.75150 & 5 & med & coastal & Red & Plane \\
\hline Middle Caicos & TCI & Swietenia mahagoni & M13 & BNM 442 & 0.709190 & -2.160 & 21.81850 & -71.75150 & 6 & small & coastal & & Plane \\
\hline Middle Caicos & TCI & Guaiacum sanctum & M14 & BNM 443 & 0.709142 & 2.610 & 21.82567 & -71.80617 & 4 & small & inland & & Plane \\
\hline East Caicos & TCI & Zanthoxylum flavum & E1 & BNM 465 & 0.709155 & 1.349 & 21.73800 & -71.59217 & 8 & med & coastal & & Plane \\
\hline East Caicos & TCI & Guaiacum sanctum & E2 & BNM 466 & 0.709186 & -1.759 & 21.73800 & -71.59217 & 8 & med & coastal & & Plane \\
\hline East Caicos & TCI & Guaiacum sanctum & E3 & BNM 467 & 0.709183 & -1.419 & 21.73800 & -71.59217 & 8 & small & coastal & & Plane \\
\hline East Caicos & TCI & Guaiacum officinale & E4 & BNM 468 & 0.709152 & 1.620 & 21.73783 & -71.59083 & 9 & small & coastal & & Plane \\
\hline East Caicos & TCI & Guaiacum officinale & E5 & BNM 469 & 0.709149 & 1.986 & 21.73800 & -71.59100 & 10 & small & coastal & & Plane \\
\hline East Caicos & TCI & Guaiacum officinale & E6 & BNM 470 & 0.709179 & -1.003 & 21.73817 & -71.59117 & 10 & - & coastal & & Plane \\
\hline East Caicos & TCI & Swietenia mahagoni & E7 & BNM 471 & 0.709179 & -1.028 & 21.73817 & -71.59133 & 8 & - & coastal & & Plane \\
\hline
\end{tabular}




$\begin{array}{rrrrrr}\begin{array}{l}\text { Island } \\ \text { Bahamas }\end{array} & { }^{87} \mathrm{Sr}{ }^{86} \mathrm{Sr} & \pm & \text { maximum } & \text { minimum } & n \\ \text { Eleuthera } & 0.709169 & 0.000020 & 0.709183 & 0.709155 & 2 \\ \text { Cat Island } & 0.709172 & 0.000002 & 0.709179 & 0.709166 & 15 \\ \text { Long Island } & 0.709169 & 0.000008 & 0.709186 & 0.709149 & 20 \\ \text { Turks \& Caicos } & & & & & \\ \text { Providenciales } & 0.709169 & 0.000012 & 0.709198 & 0.709149 & 12 \\ \text { North Caicos } & 0.709168 & 0.000011 & 0.709187 & 0.709135 & 21 \\ \text { Middle Caicos } & 0.709167 & 0.000011 & 0.709190 & 0.709142 & 14 \\ \text { East Caicos } & 0.709169 & 0.000016 & 0.709185 & 0.709157 & 7 \\ \text { Total } & 0.709169 & 0.000010 & 0.709198 & 0.709135 & 91\end{array}$




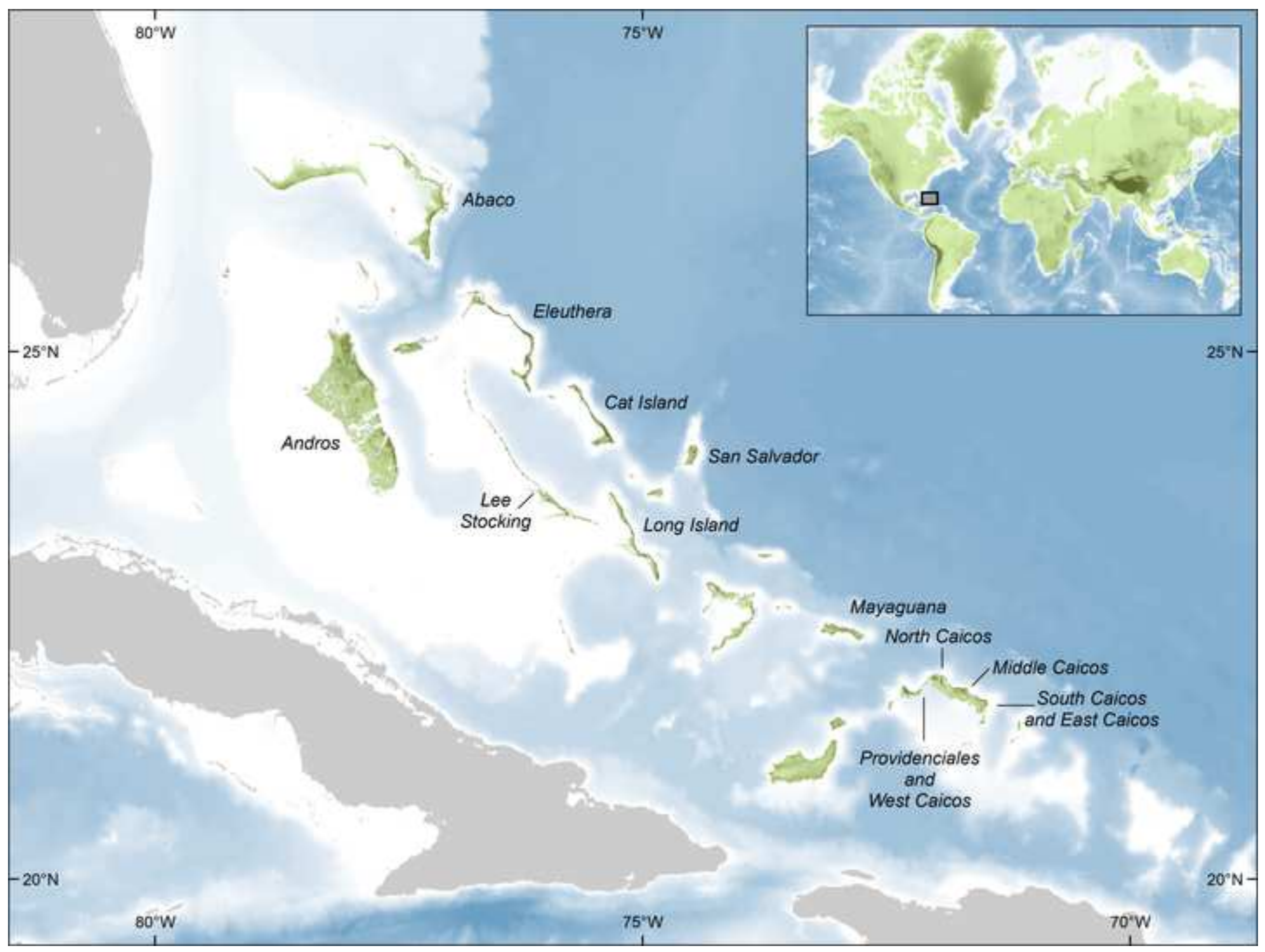




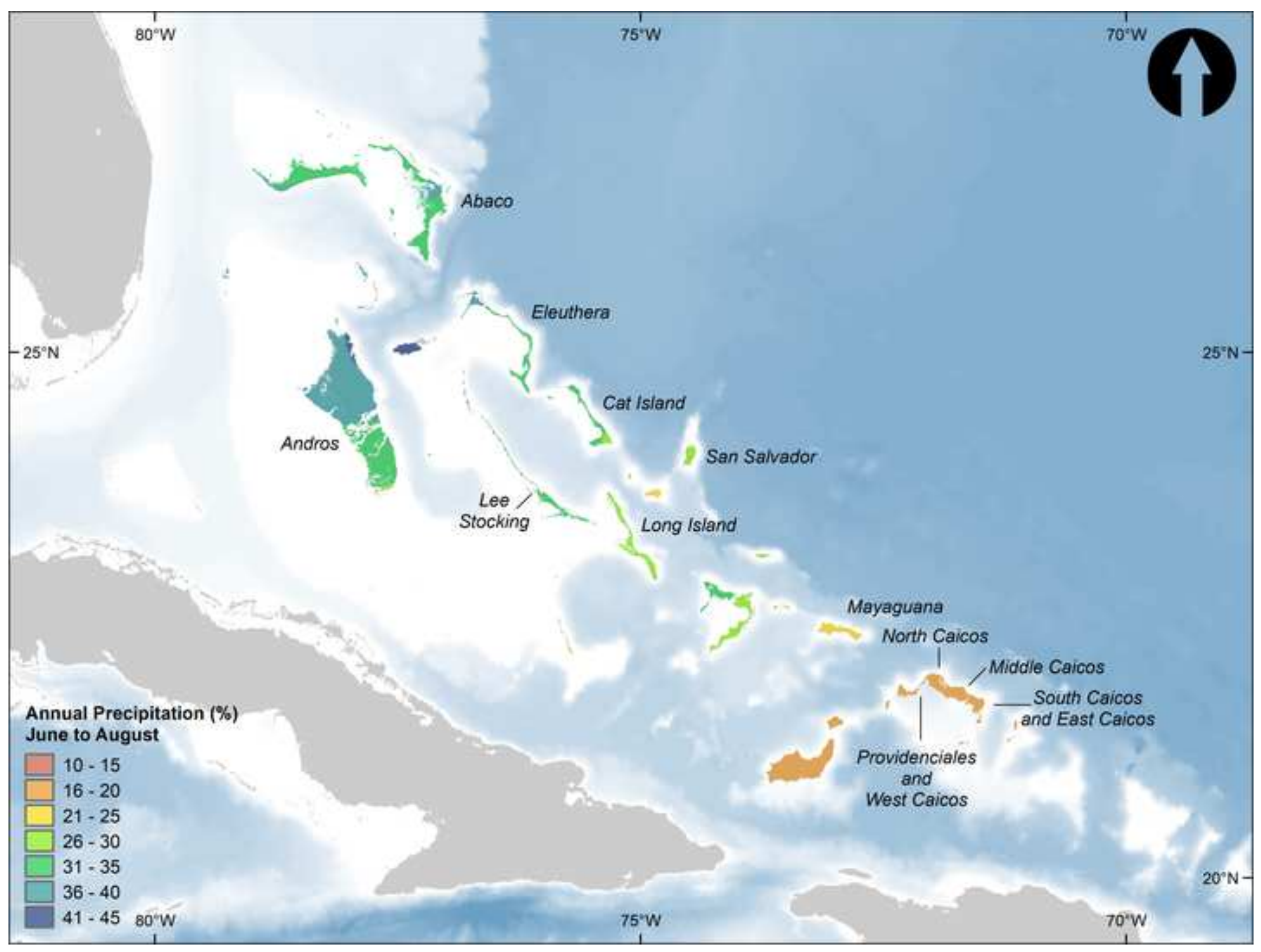




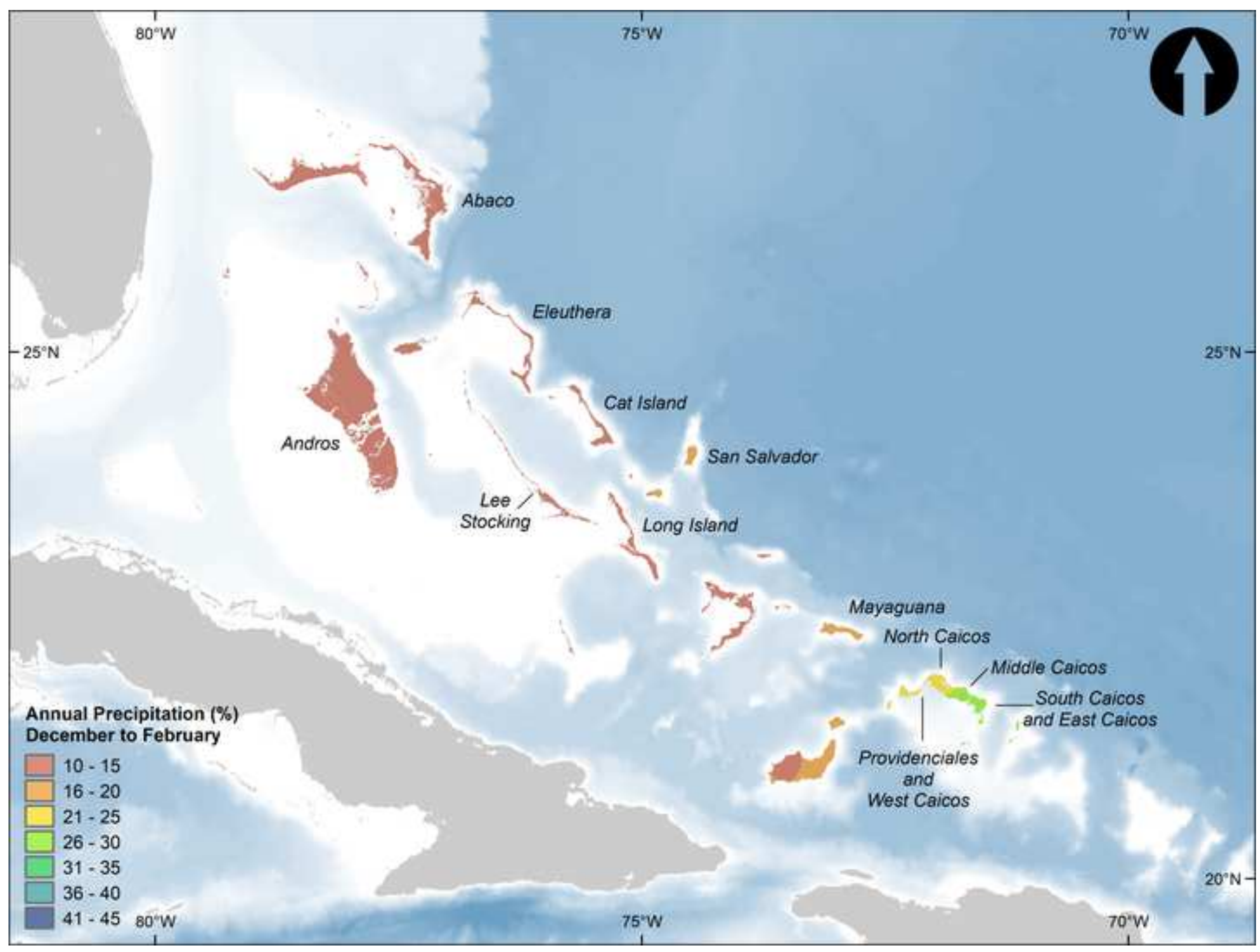




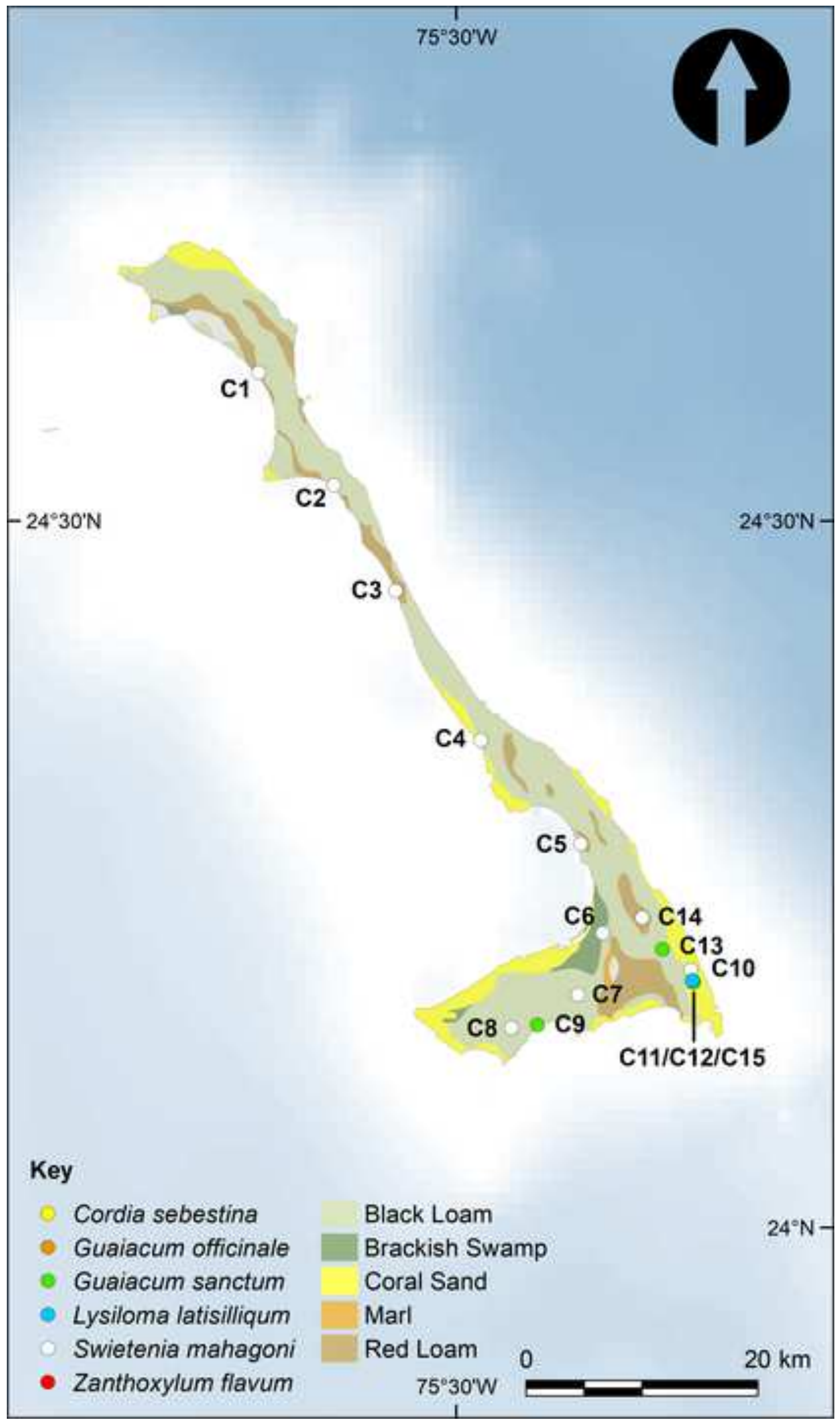




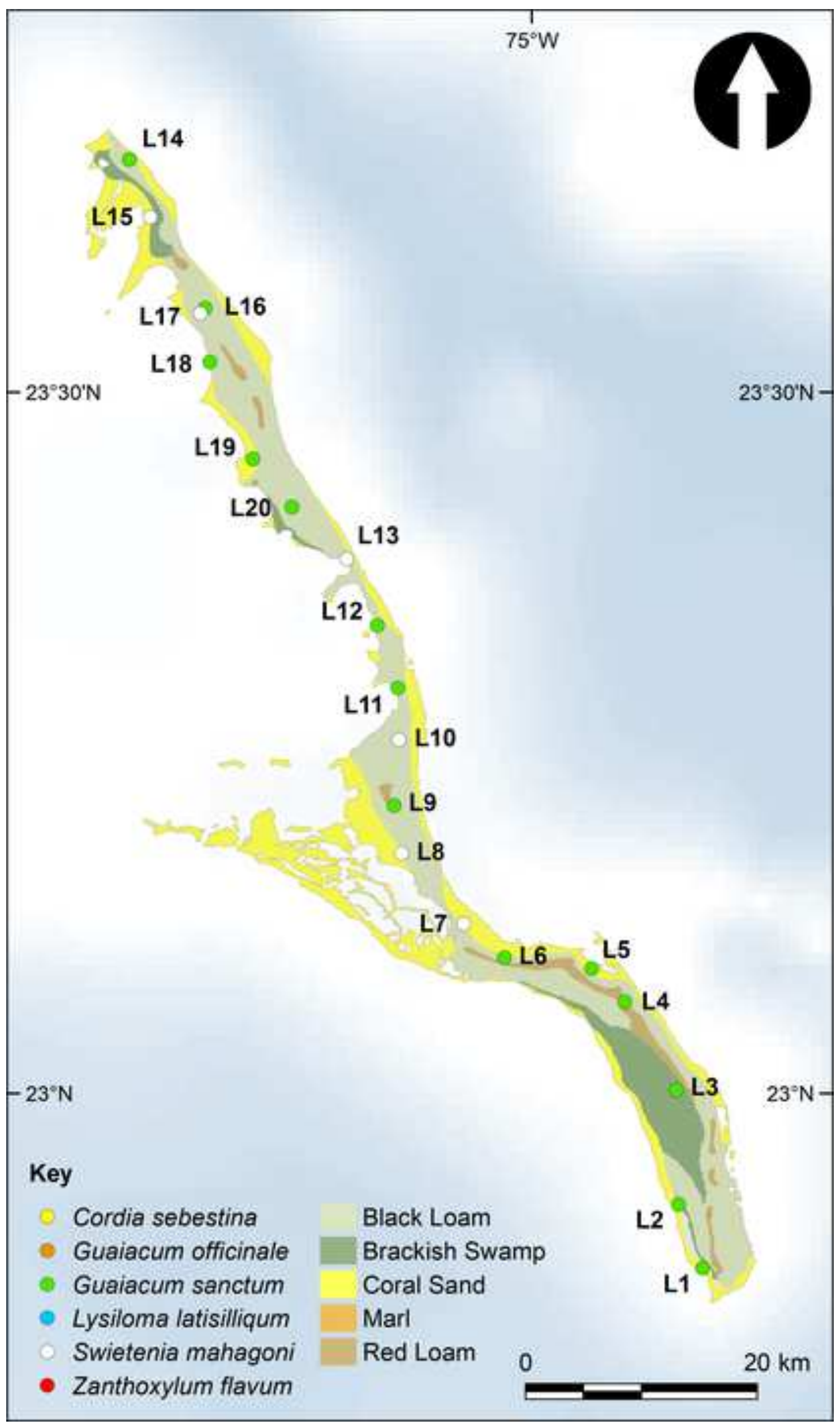




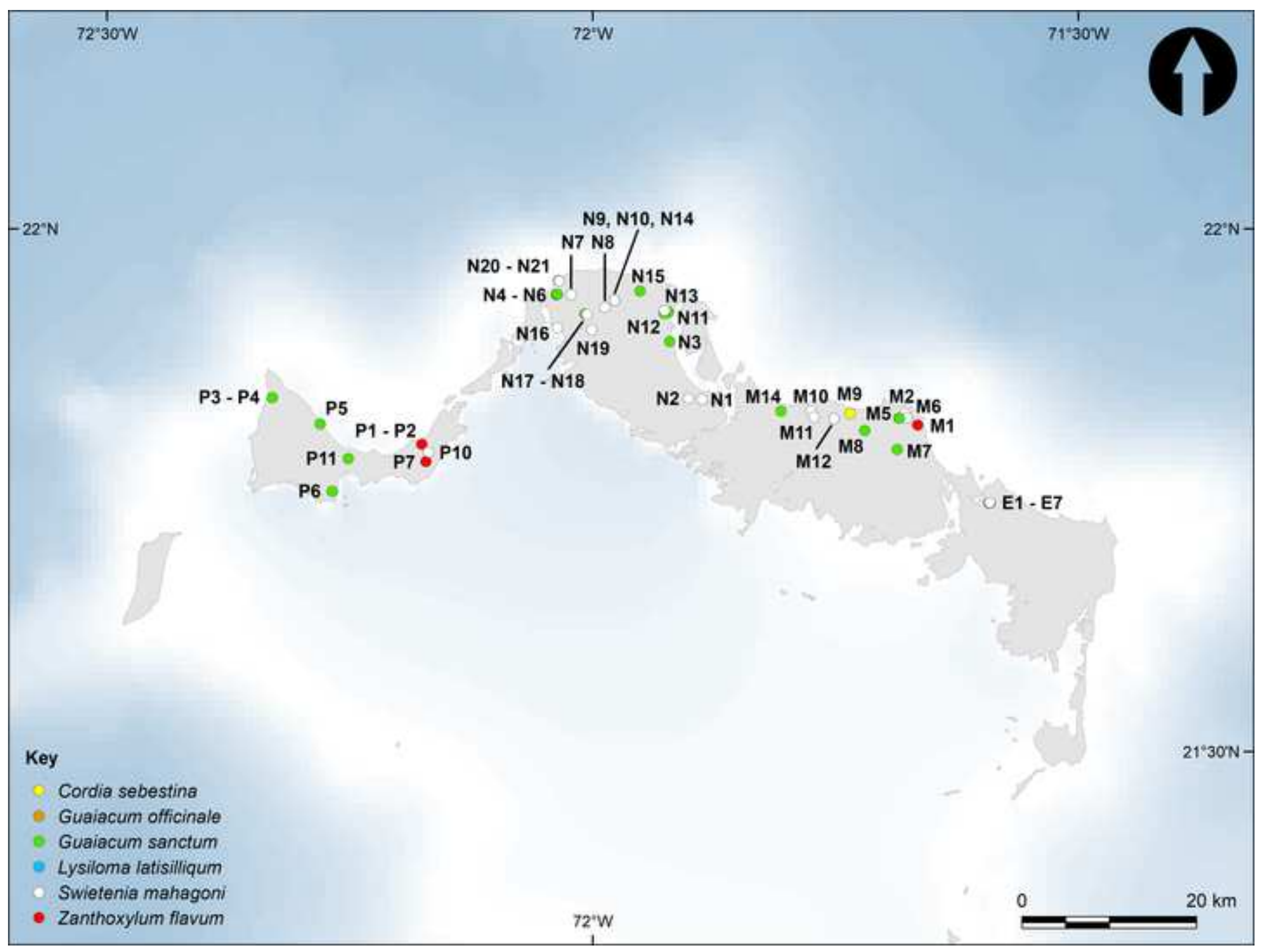

N9, N10, N14

$$
\text { N16 } \int_{\mathrm{N} 19}{ }^{\mathrm{N} 12^{\mathrm{N}}}{ }_{\mathrm{N} 3}
$$$$
\text { N2 N1 M14 M10 M9 M2 M6 }
$$$$
M 11 / \mathrm{M} \text { - } \mathrm{M7}
$$$$
\text { P7 } \bullet
$$$$
\text { P11 }
$$

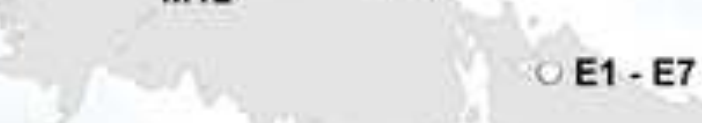

Cordia sebestina

Guaiacum officinale

Guaiacum sanctum

Lysiloma latisilliqum

Swietenia mahagoni 

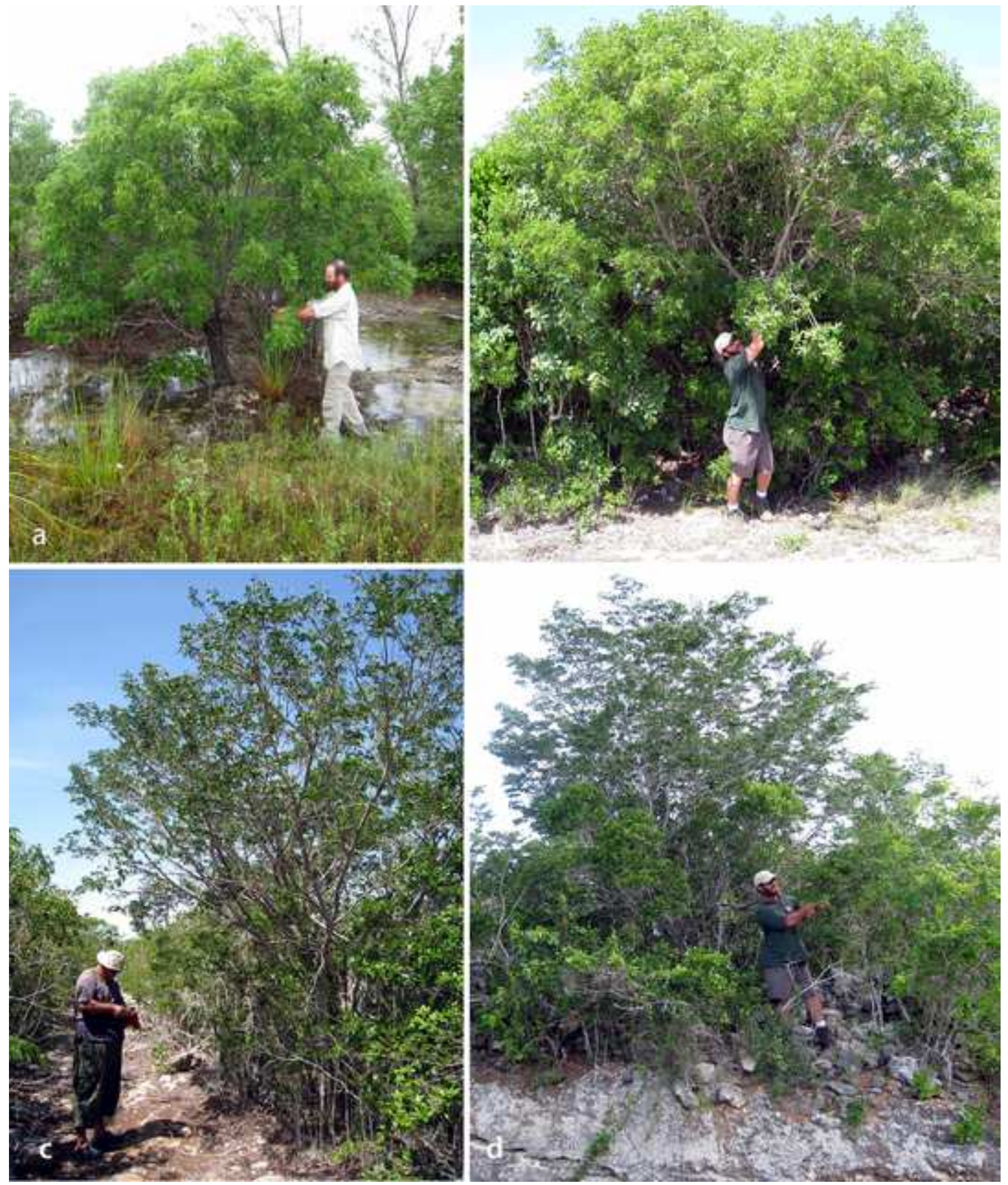


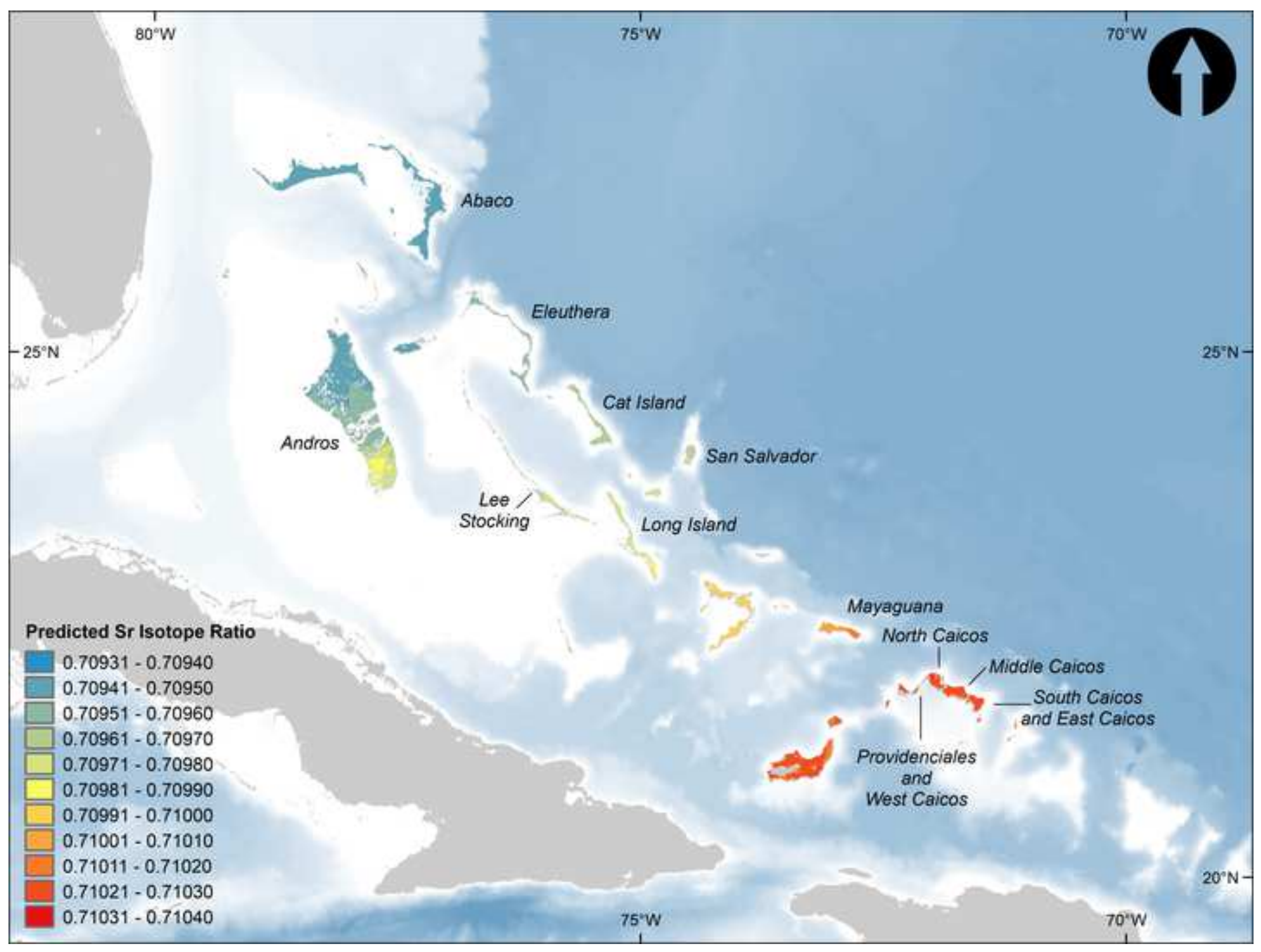

$0.70931-0.70940$

$0.70941-0.70950$

$0.70951-0.7096$

1- 0.70970

$0.71021-0.71030$ 


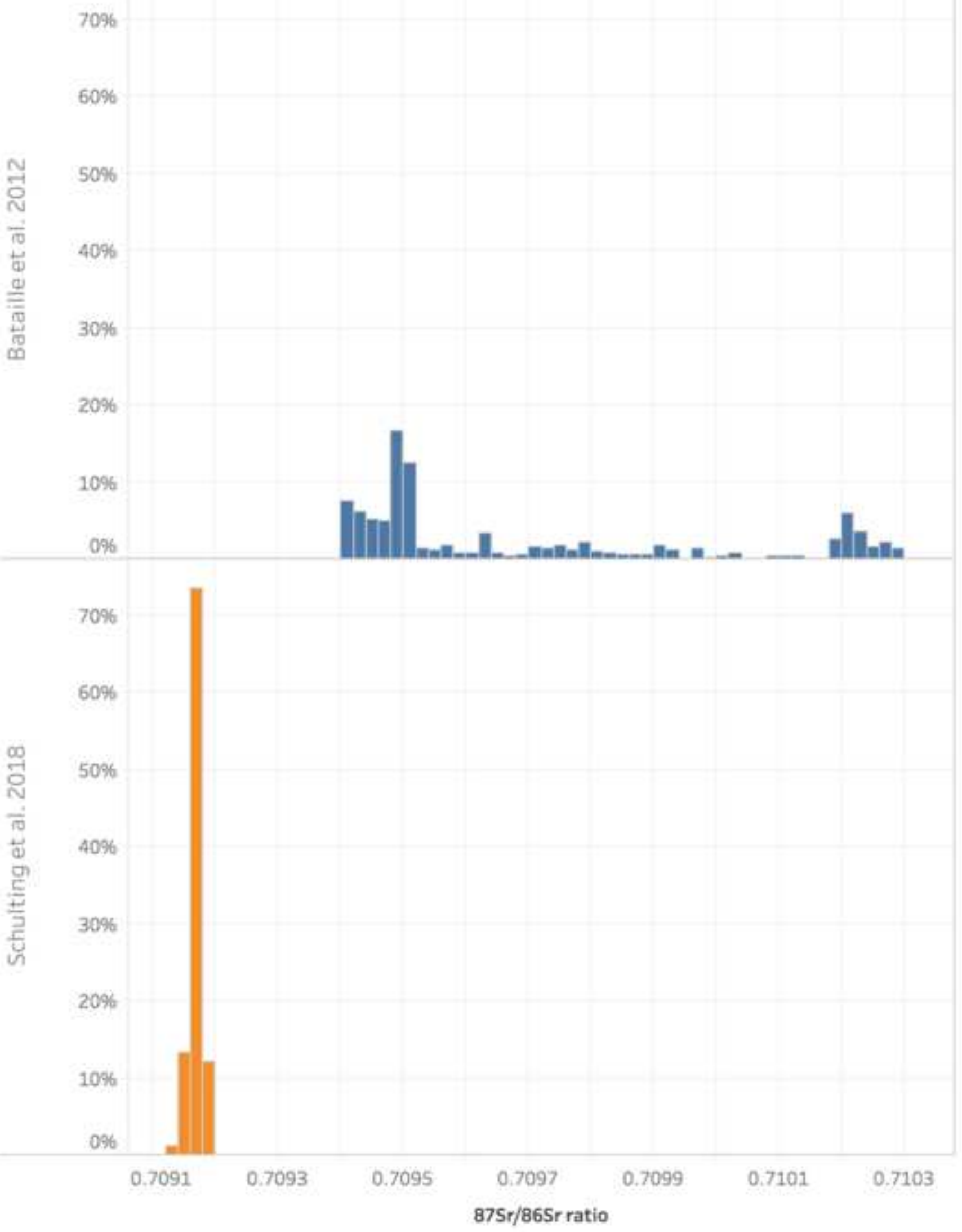




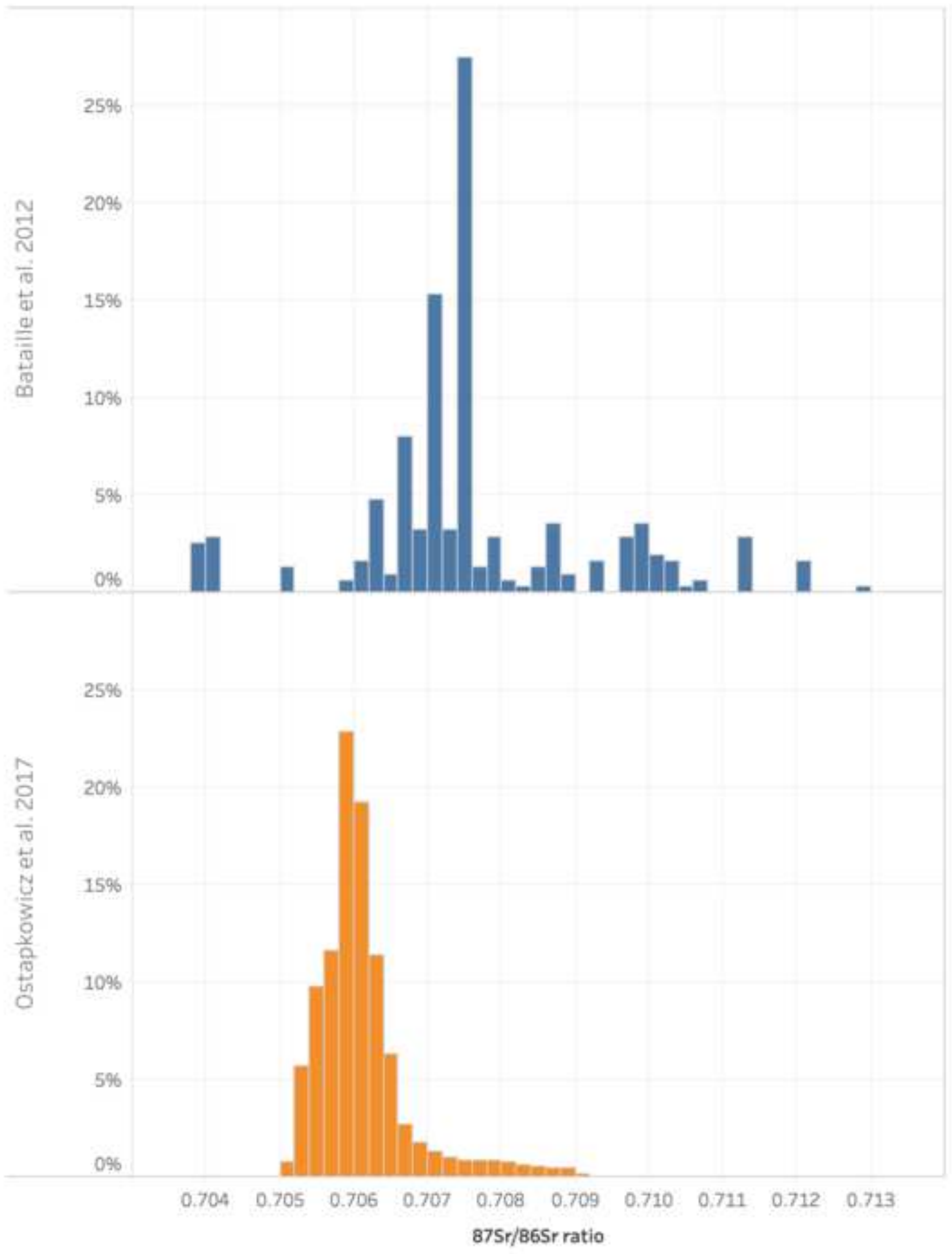

